\title{
Estimation of drug-likeness properties of GC-MS separated bioactive compounds in rare medicinal Pleione maculata using molecular docking technique and SwissADME insilico tools
}

HAKANI D SYMPLI ( $\square$ symplihakani@gmail.com )

Assam Don Bosco University https://orcid.org/0000-0002-5410-9517

\section{Research Article}

Keywords: Gas chromatography. SARS-CoV-2. Pleione maculata. Molecular docking. Drug-likeness

Posted Date: August 12th, 2020

DOl: https://doi.org/10.21203/rs.3.rs-57004/v1

License: (a) (i) This work is licensed under a Creative Commons Attribution 4.0 International License. Read Full License

Version of Record: A version of this preprint was published at Network Modeling Analysis in Health Informatics and Bioinformatics on February 24th, 2021. See the published version at https://doi.org/10.1007/s13721-020-00276-1. 


\section{Abstract}

The main aim of present paper is to determine bioactive compounds in Pleione maculata extracts using Gas chromatographic technique and to investigate their drug-likeness potential using molecular docking algorithm and ADME studies on the recent intractable disease for example; SARS-CoV-2. P. maculata sample was prepared for GC-MS analysis. The peak components are identified based on NIST Library. Molecular docking was performed using PatchDock and energy refinement was carried out using FireDock algorithm followed by druglikeness analysis using Swiss ADME tool. Mass spectrum revealed various pharmacologically important compounds and novel compounds 8-oxatetracyclo\{5.2.1.1(2,6). 1(4,10)\}Dodecane, 7-tert-Butyl-1,9,9-Trimeth, Cholesterol Isocaproate, Docosane, 2,4-Dimethyl, 7.dehydrocholesterol isocaproate, Kryptogenin 2,4-dinitrophenyl hydrazine, $\mathrm{N}$-decyl-Alpha,D-2-Deoxyglycoside, pyrimidine-2,4,6(1H,3H,5H)Trione-1-octadecyl) which are reported for the first time. Molecular docking using PatchDock illustrates GC-MS compounds Nordiazepam,3-\{N-hydroxymethyl\}aminocarbonyloxy a good docking and high binding affinity with Atomic contact energy $-10.95 \mathrm{kcal} / \mathrm{mol}$ against SARS-CoV-2 Spike protein S2 subunit. ADME analysis predict Nor-diazepam,3-\{N-hydroxymethyl\}aminocarbonyloxy and andrographolide showed very high drug-likeness parameters with no metabolism disturbances. The random control anti-viral drug arabidiol revealed a lower binding energy and lower solubility compared to bioactive compounds of $P$. maculata. The study depicts the first and novel report on various pharmaceutical important GC-MS bioactive compounds and molecular docking study of Pleione maculata having potential against various intractable diseases.

\section{Introduction}

Plants are the main source of medicines as they produce various secondary metabolites which are biologically active. These secondary metabolites provide nutritional and beneficial effect to the human health (Lakshmi and Rajalakshmi 2011). Orchids are one large kingdom of plants which are over exploited, climatic changes and their illegal trading led to extinction, biodiversity loss (Pant B 2003). Epiphytic orchid growing on other living or non-living for physical supports tend to release bioactive secondary metabolites when they are exposed to disturbance (Lindley and Paxton 1851).. Pleione maculata commonly known as the peacock orchid is a rare unexplored epiphyte on the verge of extinction (Chauhan and Sharma 2017) growing on topmost of trees at very high elevation of about 600-1600 meters (Lindley and Paxton 1851). The epiphyte is well-known medicinal plants in few of the Northeastern region of India were the local people use either the pseudobulbs or rhizome to treat liver problems, stomach ailments and headache (Pant 2003; Teoh 2016). Gas chromatography is an instrumental technique coupled with mass spectrometry applied for separation, identification and quantification of organic compounds and chemical mixtures study. An inert gas such as Helium is used as mobile phase (carrier gas). The samples to be analyze will be injected and will interact with the glass or metal column coated with stationary phase which will elute different compounds at different time called Retention time (Ghosal and Srivastava 2013). The GC-MS method is highly sensitive, reproducibility and high speed resolution (Dua and Garg 2013). A random control anti-viral drug Arabidiol was used in severe cases of COVID-19 as it was observed to reduce the viral disease (Wang et al. 2020).

A worldwide viral outbreak of dreadful disease COVID-19 arose during the month of December 2019 in Wuhan, China (Yang and Wang 2020;Yang et al. 2020).. Severe Acute Respiratory Syndrome - Coronavirus-2 (SARS-CoV-2) as named by the International Committee on Taxonomy of Viruses (ICTV) and the disease cause was named coronavirus disease 2019 (COVID-19). COVID-19 is no new virus but a possible mutation of the long known SARS-CoV-1. A genome variation analysis was analyzed using detective genome computational tool were it revealed SARS-CoV-2 shares nearly $80 \%$ similarities with the SARS-CoV gene pool (Zhang et al., 2017) with nearly 17\% variation which is a mutation occurring in spike protein, envelope protein and other respective proteins of SARS-CoV (Sardar et al. 2020). The viral genome analysis of SARS-CoV-1 open reading frame (orf) has been observed to have a potential mutation to adapt to new environment (Groneberg et al. 2005) and recombination (Li Fang 2016) which might cause severe virulence of the virus. The Severe Acute Respiratory Syndrome (SARS) is a crown-like virus or Coronavirus which was spread widely in the late 2000 over 25 countries causing thousands of cases and death (Wen et al. 2011). Since 2003, anti-viral research has been evaluated for anti-SARS-COV activity in order to prevent the reemergence of the deadly disease. The genome of SARS-CoV encodes various vital target proteins: the spike protein (S), 3CL Protease, the NTPase/Helicase, RNA-dependent RNA polymerase, membrane protein (M), envelope protein (E) and nucleocapsid phosphoprotein (N) which are involve in the virus replication, transcription and translation (Yang and Wang 2020). The main molecule that mediates coronavirus entry into host cell is their Spike protein (S) which is multi-functional (Li Fang 2016) were attachment is initiated by S1 subunit and conformation changes takes place from pre-fusion to post-fusion or membrane fusion form. The incorporation of the virus is initiated by the S2 subunit of spike glycoprotein through membrane fusion with host receptor (Rane et al. 2020). The viral 3-Chymotrypsin like protease responsible for replication complex (Anand et al. 2003) is considered highly conserved between the SARS-CoV and SARS-CoV-2 (Zhang et al. 2017; Donald and Hai-Feng 2020) The SARS-CoV spike protein has a strong binding affinity towards human receptor

Page $2 / 32$ 
Angiotensin-converting enzyme 2 (ACE2) based on structure and interaction (Zhang et al. 2020). The main agent for transmission is through respiratory droplets and can be transmitted from human to human through contact with the droplets (Yang and Wang 2020). For early diagnosis of SARS-CoV, improved RT-PCR assays can be carried out which is worldwide used for virus identification and high specificity (Shen et al. 2020). The symptoms of SARS-CoV - 1 were persistent fever, chills, dry cough, dizziness, headache, sore throat, sputum production, vomiting or nausea, special attention given for watery diarrhea. But the primary target for infection is the respiratory epithelial cells. The viral effect the immune-mediated mechanism and molecular studies showed epithelial cells of gastrointestinal tract seems to be major target cells (Groneberg et al. 2020). In 2019, various health authorities of the Hubei province in China reported the novel COVID-19 disease as pneumonia (Wu et al. 2020) or COVID-19 pnuemonia (Tian et al. 2020). Pnuemonia are a type of fatal respiratory tract infections which are caused by bacteria (Streptococcus pneumonia) or viruses on inhaling them and the symptoms of Pneumonia are no different from the deadly virus SARS-CoV-2 such as high fever, shortness of breath, rapid breathing and cough (Zafar 2016). Earlier SARS-CoV patient was treated with anti-inflammatory steroidal compound such as methylprednisolone (Groneberg et al. 2005; Wu et al. 2017) and a metabolite profiling for SARS-CoV survivors using Ultra-high performance liquid chromatography-mass spectrometry (UPLCMS) and Gas chromatography-mass spectrometry (GC-MS) were carried out after 12 years of recovery, were a significant portion (64\%) of the recovered patients were prone to lung infections and various serum metabolic disorders associated with lipid metabolism including hyperlipidemia (HL), Cardiovascular abnormality (CVA), and abnormality in glucose metabolism (AGM). Single-stranded antisense as an anti-viral compound has been a vital therapeutic area for emerging viruses (Gulam et al. 2016). Antisense therapy (Anti-sense antivirals) treats diseases using single-stranded antisense-oligo-nucleotides to target specific mRNA sequences and blocks the translation of viral protein (Gulam et al. 2016) or by modifying the protein expression (Sharad 2019). Today, In Silico studies are more favored for drug target identification in order to find the interaction of pharmaceutically important compound with their target. The most commonly known computational tool for drug-target is molecular docking using various algorithms. PatchDock is highly efficient (Prabhu and Rajeswari 2016) accurate (Doss et al. 2014), fast transformational search and free-online server in comparison to other computational molecular docking server. PatchDock is a molecular docking algorithm based on the principle of shape complementarity. A complementarity molecular shaped is yield forming a conformational transformation of each docking molecule known as induced fit. The transformed molecules can be further evaluated based on the scoring function which involves geometric-fit and atomic contact energy (ACE). PatchDock algorithms contain three stages, (a) Molecular shape representation based on geometric patches (Concave, convex and flat surface pieces) (b) Surface patch matching and (c) Filtering and scoring (Duhovny et al. 2002). Various parameters are involved for running a docking interaction between molecules such as the Root Mean Square Deviation (RMSD) and a complex type. The RMSD is applied to prevent redundant solution of molecule and is exact (Duhovny et al. 2002). PatchDock uses technique such as geometry hashing and pose clustering which are advance data structures and spatial pattern detection. In Docking, energy refinement is required for further development of drug compound using FireDock (Andrusier et al. 2007; Surana et al. 2018). The FireDock (Fast iteration refinement in molecular docking) refinement of energy uses Monte Carlo minimization of binding score and it is highly efficient, easy to understand and requires no prior knowledge in docking (Lipinski et al. 1997). The score are Atomic Contact Energy (ACE), softened Van der Waals interaction, partial electrostatics and additional estimation of the binding energy. FireDock algorithm includes three refinement steps (1) Side-chain optimization (2) Rigid-body minimization and (3) Scoring and ranking (Lipinski et al. 1997). The docking analysis can be predicted base on the highest binding affinity and lowest docked energy (lyamah et al. 2017). Prior to clinical studies which are time consuming and not cost effective, drug-likeness of compounds can be primarily analyzed using computational tools. Swiss ADME a free web tool to evaluate pharmacokinetics based on different drug-likeness parameters are predicted such as physicochemical properties, solubility and pharmacokinetics of molecule (Daina et al. 2003).

To-date, there has been a lot of controversies regarding vaccine or drug development against SARS-CoV-2 pnuemonia, therefore a compound separation technique using Gas chromatography-Mass spectrophotometry was performed for the epiphytic medicinal orchid Pleione maculata with the intention to provide a preliminary basic ideas on different bioactive compounds present in medicinal plants which might have potential against dreadful diseases. A phytochemical studies and anti-microbial activity of Pleione maculata was also reported to have distinct zone of inhibition against Streptococcus pneumonia (Sympli et al. 2019)· With prior knowledge using steroidal compound and antisense target for treatment of other viral disease in the earlier years, a few of the GC-MS compounds of Pleione maculata were known to have steroidal anti-viral bioactive compound as well as an antisense target compound. Based on the symptoms and side-effects after recovery from SARS-CoV patient, various bioactive compounds which might have the potential for the following were preliminary investigated for their drug-likeness using Molecular docking algorithm using PatchDock. A random control anti-viral treatment of COVID-19 arabidol was used for comparison with the bioactive compounds.

The present paper analyzed different bioactive compounds present in Pleione maculata using GC-MS technique and to evaluate their druglikeness potential having multi-target bioactivity using molecular docking algorithm to observe the binding energy as well as the conformational fit between the bioactive compounds of $P$. maculata against target proteins, SARS-CoV-2.

Page $3 / 32$ 


\section{Materials And Methods}

\subsection{Collection and extract preparation of plant material}

Pleione maculata samples were collected from top tree trunks in the dense forest of Khliehriat, East Jaintia Hills regions of Meghalaya for the processing. The parts of $P$. maculata was washed under running tap water, followed by surface sterilization with distilled water, $1 \%$ sodium hypochlorite and re-washed with distilled water. The samples were shade dried until use. The samples were crushed and each plant part was soaked in three different solvents such as ethanol, methanol and acetone followed by incubation 24-48 hours. The crude extract was filtered using Whatman filter paper No 1 (Vijisaral and Arumugam 2014). The solvent extracts are then evaporated by using open-air evaporation in the laminar air flow hood for 24 hours and centrifuged at $12,000 \mathrm{rpm}$ for about 15 minutes at $4^{\circ} \mathrm{C}$. The concentrated extracts was the transferred into micro-centrifuge tube for GC-MS analysis.

\subsection{GC-MS analysis and Identification of compounds}

In oven, the initial temperature was $110^{\circ} \mathrm{C}$ for 3 minutes (Thomas et al. 2013), then increased for $5^{\circ} \mathrm{C} / \mathrm{min}$ to $200^{\circ} \mathrm{C}$ and held for 3 minutes and again increase for $5^{\circ} \mathrm{C} / \mathrm{min}$ to $300^{\circ} \mathrm{C}$ and held 10 minutes (Darmasiwi et al. 2015). Injector and ion source temperature were $280^{\circ} \mathrm{C}$ and $180^{\circ} \mathrm{C}$, Injection volume was $1 \mu \mathrm{L}$, and the spilt ratio was 0:1. Carrier helium gas was used through the column. Solvent delay by $9.00 \mathrm{~min}$ and transfer temperature was $200^{\circ} \mathrm{C}$. The sample was scan from 40 to $600 \mathrm{Da}$. The chromatography was performed on a column of $60.0 \mathrm{~m}$ $x 250 \mu \mathrm{m}$.

\subsection{Identification of components by using NIST}

The National Institute of Standards and Technology (NIST) are a mass spectral search databases for comparisons of acquired and unknown spectrum with the NIST/EPA (Environmental protection Agency)/NIH (National Institute of Health) Databases. The components are identified based on the standards employed by the National Institute Standards and Technology (NIST) Library (Darmasiwi et al. 2015). The detection is employed by comparing the peaks with that in the Mass spectral standard reference data of NIST having more than 62 , 000 patterns.

\subsection{Molecular docking using PatchDock}

\subsubsection{Input}

Protein structures retrieval: Protein receptor target was retrieved from Protein Data Bank (PDB) in 3D structure as shown in Fig. 1. The following three target receptors are (1) SARS-CoV-2-3CL protease (PDB ID: 6M2Q), (2) SARS-CoV-2 RNA-dependent RNA-Polymerase (PDB ID: 6M71) and (3) SARS-CoV-2 spike glycoprotein receptor S2 subunit (PDB ID: 6LXT)

\subsubsection{Ligand retrieval}

A total of 19 ligand molecule ass shown in Fig. 2 was retrieved from PubChem database in SDF file format and using PyMol the small ligand was converted into PDB format (Prabhu and Rajeswari 2016; Yadav et al. 2017). The 3D-structures with compound CID: 6211 (2,4,6Pyrimidinetrione), CID: 248856 (21-acetoxypregenelone), CID: 543946 (P-menth-8(10)-en-9-ol), CID: 541761 (Nor-diazepam, 3-Nhydroxymethyl,aminocarbonyloxy), CID: 441207 (Digitoxin), CID: 19089489 (DI-N-Decylsulfone), CID: 3893 (14-dodecanoic acid), CID: 13948 (Estra,13,5 (10)-trien-17-beta-ol), CID: 5283405 (Arachidonic amide, N-5-hydroxy-N-pentyl), CID: 572031 (1-methylsulfanyl-9,10Dioxo-9,10-dihydro-anthracene-2-carboxylic acid), CID: 14077841 (Cholesterol margarate), CID: 8215 (Docosanoic acid), CID: 99470 (26hydroxy cholesterol), CID: 5318517 (Andrographolide), CID: 135426867 (6H-purin-6-one-1,7-dihydro-2-methylamino), CID: 261799 (Pseduosarsasapogenin), CID: 71360559 (Oxiraneundecanoic acid, 3-pentyl, methyl ester,cis), CID: 5486971 (Pregabalin), CID: 131411(Arabidol)

\subsubsection{Molecular Docking analysis}

Protein-Small ligand molecule docking was performed using PatchDock algorithm (Prabhu and Rajeswari 2016;Yadav et al. 2017;Surana et al. 2018). The parameters was set, were complex type was selected for protein-small ligand molecules, Clustering root mean square deviation (RMSD) was set to $1.5 \AA$ for protein-ligand interaction. The protein receptor was uploaded in PDB format also the small ligand molecule was uploaded followed by the form submission. The following output will be further sent by PatchDock to the given email ID. A 1000 docking candidate generated from PatchDock in their transformation form were refined and scored using FireDock. The result was then visualized using PyMoL a molecular visualization graphics system tool. 
2.4.4 Drug-likeness analysis of bioactive compounds using Swiss ADME tool (Daina et al. 2003)

Chemical structure of compounds were downloaded from PubChem data bank in SDF (structure data format) and Swiss ADME web page was opened and the file was imported from the external file option and was converted into molecular sketcher based on ChemAxon's Marvin JS followed by ADME calculation using default parameters.

\section{Results And Discussion}

GC-MS analysis reported more than 146 hits and lead compounds from different parts of $P$. maculata. The compounds identified from the acetone leave extracts were more as compared to the other solvent extracts. The following hit and lead compounds of $P$. maculata with their bioactivity are listed on Table 1, Table $2 \&$ Table 3. The GC-MS analysis of other orchids mostly focuses on the flower scent profile rather than medicinal profile, for example Vanda species (Darmasiwi et al. 2015), Rhynchostylis gigantean Ridl, Rhynchostylis gigantean var. harrisonianum Holtt., Vanda coerulea and Dendrobium parishii Rchb. F., (Julsrigival et al. 2013) and Dendrophylax lindenii (Sadler et al. 2011). The GC-MS report of Pleione maculata in the paper mainly focused on total medicinal important compounds present in different parts of the epiphyte. Compounds such as Phenol 4-(ethoxymethyl), Heptacosanoic acid methyl ester, 9-octadecanoic acid (Z)- 2-Hydroxy1-(hydroxymethyl) ethyl ester (Vijisaral and Arumugam 2014; Rajalakshmi and Mohan 2016), Nonanoic acid 9(3hexemyldenecycyclopropylidene-2-hydroxy-1-1 (HYD) (Sahin et al. 2006) , Alpha-ketostearic acid ethyl ester, 1-naphthaleneproponal alphaethyl Decahydro-5-(hydroxymethyl), Cis Cis Cis-7,10,13-Hexadecatrienal (Prabhadevi et al. 2012; Abdulaziz et al. 2019), 1H-Purin-2-amine-6methoxy, 4-cyanobenzoic acid Tridec-2-YNYL ester, Alpha-L-Fucopyranose 1,2.3,4-Bis (Benzeneboonate), cholesterol margarate, 2.pyridinecarboxylic acid 6-methoxy, 1-methyl sulfanyl -9-10-Dioxo-9,10-dihydro-anthracene-2-carbxylic acid, pyrimidine-2,4,6(1H,3H,5H)Trione-1-octadecyl), E,E-1,9,17-Docasatriene Subavathy and Thilaga 2016; Kumaravel et al. 2019), N-decyl-Alpha D-2-Deoxyglycoside are few of the compounds which were identified but have no bioactivity reported before from other papers. Compounds 8oxatetracyclo\{5.2.1.1(2,6). 1(4,10)\}Dodecane, 7-tert-Butyl-1,9,9-Trimeth, Cholesterol Isocaproate, Docosane, 2,4-Dimethyl, 7.dehydrocholesterol isocaproate, Kryptogenin 2,4-dinitrophenyl hydrazine, $\mathrm{N}$-decyl-Alpha,D-2-Deoxyglycoside, pyrimidine-2,4,6(1H,3H,5H)Trione-1-octadecyl) are some of the novel compounds which have not been reported earlier.

Molecular docking study was performed for nineteen GC-MS compounds using PatchDock with energy minimization and structure refinement using FireDock was analyzed. The selected compounds for docking were based on their bioactivity against symptoms related to the SARS-CoV-2 pneumonia such as anti-inflammatory activity, prevent cardiac insufficiency, prevent fatique, prevent shortness of breath, prevent gastrointestinal diseases, heart beat improvement, anti-viral activities and compound having repellent activity, larvicidal activity on the basis of earlier knowledge of using anti-malarial drug for reducing the viral load (Rane et al. 2020). The targets were docked properly as the binding energy was shown to be negative and the docked ligand RMSD value is $₫ 2.0 \AA$ (Singh et al. 2017). The binding residues and Atomic contact energy of ligands against the target proteins are listed in Table 4. The highest binding energy of docked molecule was considered below $-6.00 \mathrm{kcal} / \mathrm{mol}$ (higher negative value) higher binding energy then higher the binding potential between molecules. The different GC-MS compounds interacted with numbers of residues on the side-chain and backbone of the target protein as shown Fig. 4, Fig. 5 and Fig. 6. A non-covalent (polar) interaction was observed between the docking molecules at a closer distance of 1.5A. All the docked molecules showed zero hydrogen bonding between them but formed a specific electrostatic, van der Waals interaction and some interacted with the positively charged functional groups of amino acid (Lysine, arginine, histidine) while some interacted with the hydroxyl groups of amino acid Serine, Threonine and Tyrosine. Amino acid residues such as Serine, Threonine and tyrosine contribute rotating hydroxyl groups between docked molecules are considered rigid (Pantsar and Poso 2018).

\subsection{Docking analysis of the SARS-CoV-2 RNA-dependent RNA - polymerase (PDB ID - 6M71)}

The target protein RNA-dependent RNA-polymerase residues interacted with GC-MS compounds based on lowest binding energy, Digitoxin, cholesterol maragarate, Docosanoic acid, Pseduosarsasapogenin-5,20-dien, Arachidonic amide,N-\{5-hydroxy-N-pentyl), DI-N-Decylsulfone, Oxiraneundecanoic acid,3-pentyl,methyl ester,cis, andrographolide, 21-acetoxypregenelone, p-menth-8(10)-en-9-ol, 26-hydroxycholesterol and Pregabalin with high atomic contact energies $-22.96,-21.60,-13.13,-12.54,-12.04,-11.57,-11.38,-8.43,8.38,-7.18,-7.11$ and -6.85 $\mathrm{kcal} / \mathrm{mol}$. The most prominent and common amino acid residues binding to the target protein were Asn 414, Lys 411, Tyr 141, Val 12, Tyr 546 and Asn 781.

\subsection{Docking analysis of ligands against target SARS-CoV-2 3CL Protease (3CL pro) (PDB ID - 6M2Q)}

GC-MS compounds of $P$. maculata Digitoxin, 26-hydroxycholesterol, 1-methylsulfanyl-9,10-Dioxo-dihydro-anthracene-2-carboxylic acid, Arachidonic amide,N-\{5-hydroxy-N-pentyl), cholesterol margarate, 21-acetoxypregenelone, pseduosarsasapogenin-5,20-dien, DI-Ndecylsulfone,, Nor-diazepam,3-\{N-hydroxymethyl\}aminocarbonyl, Andrographolide, p-menth-8(10)-en-9-ol and pregabalin with high binding 
energies $-13,27,-12.61,-12.22,-10.86,-9.91,-9.22,-8.41,-7.39,7.19,-7.17,6.75$ and $-6.33 \mathrm{kcal} / \mathrm{mol}$ against the target SARS-CoV-2 3CL protease. The most commonly found amino acid residues binding to the target pocket are Gln 110, Phe 294 and Thr 111.

\subsection{Docking analysis of ligands against the target SARS-CoV-2 post-fusion core structure of spike glycoprotein S2 subunit (PDB ID- 6LXT)}

The target Spike glycoprotein-S2 subunit amino acid residues interacted with compounds, 1-methylsulfanyl-9,10-Dioxo-9,10-dihydroAnthracene-2-carboxylic, Nor-Diazepam, 3-\{N-hydroxymethyl\} aminocarbonyloxy, andrographolide, Digitoxin, cholesterol margarate, 26hydroxycholesterol, p-menth-8(10)-en-9-ol and pregabalin with high binding energies of $-10.95,-9.23,-8.93,-8.23,-8.23,6.68$ and 6.29 $\mathrm{kcal} / \mathrm{mol}$. The most common residues binding to target proteins are Ser 943, Ser 940, Glu 1188, Ser 939, Asp 1184, Asp 936, Lys 1191, Gln 935, Asn 1187.

\subsection{Drug-likeness analysis of bioactive compound}

Drug-likeness was analyzed to check whether they possess favorable ADME (Absorption, Distribution, metabolism, excretion) properties. Drug-likeness analysis of bioactive compounds is listed on Table 5 with their different parameters as shown in the bioavailibity radar Fig. 7. Nor-diazepam,3-\{N-hydroxymethyl\}aminocarbonyloxy, a bioactive compound which shows a good binging affinity against SARS-CoV-2 shows high drug-likeness parameters with good solubility property, no excretion problems as there is no pharmacokinetics P-gp (Permeability-glycoprotein) interference and non-inhibitor of CYP enzymes and compound is specific in nature as there is zero alerts for PAINS (pan assay interference compounds). 1-methylsulfanyl-9,10-Dioxo-9,10-dihydro-anthracene-2-carboxylic acid drug-likeness parameters is good since it follows the Lipinski, Ghose, Veber, Egan, Muegge rule and Bio-availability score 0.55 but the PAINS (Pan assay interference compounds) shows some interference with Quinone A compound therefore the compound is not specific in nature and is moderately soluble in nature. Digitoxin, might have shown good binding affinity but do not obey any of the drug-likeness parameters. Pregabalin and P-menth-8(10)-en-9-ol bioactive compound are highly soluble in nature but does not obey all the drug-likeness parameters due to molecular weight $\$ 160$. 21-acetoxypregenolone an antisense target compound showing good binding affinity against SARS-CoV-2 shows moderate drug-likeness parameters, specific in nature and no excretion problems but is an inhibitor of CYP2C9 enzyme. Pseduosarsasapogenin-5,20-dien and Andrographolide drug-likeness activity is moderate with good solubility property. Compounds such as DI-N-decylsulfone, Arachidonic amide,N-\{5-hydroxy-N-pentyl\}, 26-hydroxycholesterol, Cholesterol margarate and Docosanoic acid showed poor solubility with low drug-likeness properties. Arabidiol an already marketed anti-viral drug does follow the Lipinski rule of five but does not obey the drug-likeness parameters and is poorly soluble compared to the bioactive compounds of Pleione maculata with high solubility in nature.

A phytochemical test for $P$. maculata also depicts the presence of various phytochemical compounds in different parts of the epiphyte (Sympli et al. 2019).Docking involves interaction of various polar and non-polar groups were both play a significant role in the stability of protein-ligand interactions. In Docking, water solvent is removed by most programs as they tend to form hydrogen bonds with molecules either as donor or acceptor (Pantsar and Poso 2018). Protein-ligand interactions are strong on removal of $\mathrm{H}$-bond but in association with other non-covalent interactions such as electromagnetic interactions, ionic interactions, van der waal interaction and hydrophobic interactions plays an important role in protein-ligand stability (Yadav et al. 2017). Van Der Waals interactions are non-covalent intermolecular interactions which can be repulsive or attractive interaction, bonding energy decreases from zero to its negative value, when the distance of attraction between two molecules are close whereas repulsive forces occurs when the distance of separation decreases and bonding energy increases (Singh 2016). Van der Waals interaction may be considered weak but they play a vital role in structure and biomolecules interaction. Hydrogen bonds are also weak non-covalent bond which induces thermal fluctuation in energies and tend to form or break rapidly causing conformational changes during binding (Bronowska 2011). Drug-likeness compounds should have a good aqueous solubility which is predicted by three methods ESOL, (ALI) logS and (SILICOS-IT) logS (Mishra and Dahima 2019). Orally active drug should also obey the Lipinski five rule; Molecular weight (MW) not more than $500 \mathrm{~g} / \mathrm{mol}$, Hydrogen bond acceptors should not be more than 10, hydrogen bond donors not more than 5, LogP value less than 5 and number of rotatable bonds not less than 10 (Lipinski et al. 1997).GC-MS bioactive compound Nor-diazepam,3-\{N-hydroxymethyl\}aminocarbonyloxy , Andrographolide, depicts a high binding energy $-10.95,-9.23 \mathrm{Kcal} / \mathrm{mol}$ and as well as very high drug-likeness properties when compared to the binding energies of Fisetin, quercetin, isorhamnetin, genistein, luteolin, resveratrol and apigenin with $-8.5,-8.5,-8.3,-8.2,-8.2,-7.9,-7.7 \mathrm{Kcal} / \mathrm{mol}$, respectively against $\mathrm{S} 2$ subunit spike glycoprotein (Rane et al. 2020). Compounds Nor-diazepam,3-\{N-hydroxymethyl\}aminocarbonyloxy, Andrographolide, pregabalin, Pmenth-8(10)-en-9-ol, 21-acetoxypregenolone, 1-methylsulfanyl-9,10-Dioxo-9,10-dihydro-anthracene-2-carboxylic acid are few of the druglikeness compounds which meets the characteristics to be a drug such as solubility, Lipophilicity (Log P) less than 5, hydrogen bond not more than 5. Most of the compounds predicted showed good solubility and good absorption. The drug-likeness parameters describe is the main criteria for primary drug development. The bioactive compounds of $P$. maculata screened using GC-MS has more potential as drug-

Page 6/32 
likeness against various intractable diseases for example here; SARS-CoV-2 pnuemonia (COVID-19) because of its stronger binding energies, closer interaction and abide by the ADME characteristics.

\section{Conclusion}

GC-MS analysis in methanol, ethanol and acetone extracts of different parts (Leaves, stem and roots) of $P$. maculata identified major peaks indicating the presence of phytochemical constituents such as Palmitic acid, Vitamin E, Vitamin A precursor, Cardiac glycoside, Ascorbic acid, Linoleic acid, oleic acid, stearic acid, alkaloid, di-terpenoid, flavonoid, phenolic and steroidal compound. Cholestenone compound which has the capability to suppress fat accumulation and anti-obesity activity is not commonly found in other medicinal plants but reported in the GC-MS study of $P$. maculata. The identified compounds were known to have various activities commonly antimicrobial, antiinflammatory, antioxidant, cancer preventive, hypocholesterolemic, nematicide, antiasthma, anti-arrhythmic activity (improve heart beat), anti-viral activity, larvicidal activity, anti-convulsants and anti-obesity activities. Molecular docking analysis is one of the structure based designing of drugs. The compounds of $P$. maculata showed a highly effective binding affinity and high atomic contact energy. The spike glycoprotein S2 subunit of SARS-CoV-2 was one of the rigid target as it initiates membrane fusion with the host receptor but bioactive compound Nor-diazepam,3-\{N-hydroxymethyl\}aminocarbonyloxy showed a very good docking and high binding affinity with Atomic contact energy $-10.95 \mathrm{kcal} / \mathrm{mol}$ and very high drug-likeness properties. For centuries, plants are the main source of medicinally important natural products. The paper represents the first report on the GC-MS analysis, molecular docking and drug-likeness study of $P$. maculata. The findings are expected to contribute a significant and major therapeutic impact in the pharmaceutical companies. An in-vitro and in-vivo analysis has to be implemented to know the mechanism of action, cytotoxicity studies of the above effective bioactive compounds. In conclusion, the study on rare Pleione maculata highlights their prospective therapeutic potentialities against various intractable diseases and their bioactive components will enhance a sustainable rural livelihood in both primary and secondary health care and also to save them from extinction and over-exploitation. The effective drug-likeness compound does not have to be separated or isolated directly from the sources plant but the study will provide a basic idea on the synthetic production of effective bioactive compounds.

\section{Declarations}

\section{Acknowledgement}

I thank Dr. Mahua Gupta Choudhury, MSc. dissertation guide, Dr. Vedant V. Borah, Doctoral research guide for their support. Also I would like to thank Dr. Supriyo Sen for introducing me to Indian Institute of Technology (IIT), Biotech Park Guwahati, Assam, for GC-MS analysis. I sincerely acknowledge the School of Biosciences, Assam Don Bosco University for permitting and providing me with basic requirements for the methodology part. Lastly I acknowledge Dr. Rajiv Chandra Dev Goswami, IIT, Guwahati for the guidance and information on GC-MS analysis. The work is financially supported by Ministry of tribal affair, Govt. of India (Ref: 201819-NFST-MEG-00850)

\section{Conflict of interest}

The author declares no conflict of interest. The research work is original

\section{References}

1. Abdulaziz AA, Dabar MLG, Manting MM, Torres MAJ, Aranas AT, Mindo RAR, Cabrido CK, Demayo CG (2019) Qualitative evaluation of the antimicrobial, antioxidant and medicinally important phytochemical constituents of the ethanolic extracts of the leaves of Gliricidia sepium (JACQ) WALP. Pharmacophore 10(4): 72-83. ISSN-2229-5402

2. Abubakar NM, Majinda TRR (2016) GC-MS analysis amd Preliminary antimicrobial activity of Albizia adianthifolia (Schumach) and Pterocarpus angolensis (DC). Medicines 3(3):1-9. https://doi.org/10.3390/medicines3010003

3. Adeoye-Isijola OM, Olajuyigbe 00, Jonathan GS, Coopoosamy MR (2018) Bioactive compounds in ethanol extract of Lentinus squarrosulus Mont- A Nigerian medicinal macrofungus. African Journal of Traditional, Complementary and alternative medicines 15(2): 42-50. https://doi:1021010/ajtcamv15i2.6

4. Agboke AA, Attama AA (2016) Bioactive components and antibacterial activities of n-Hexane extract of Moringa oleifera root bark on clinical isolates of methicillin resistant Staphylococcus aureus. International Journal of current research in chemistry and pharmaceutical sciences 3(3): 1-9. https://s-o-i.org/1.15/ijcrcps-2016-3-3-1

5. Agrawal A, Srivastava K, Puri SKK, Chauhan PMS (2005) Synthesis of 2,4,6-trisubstituted pyrimidines as anti-malarial agents. Bioorganic \& Medicinal chemistry. 13(5): 4645-4650. https://doi.org/10.1016/j.bmc.2005.04.061

Page 7/32 
6. Alagammal M, Soris PT, Mohan VR (2012) GC-MS analysis of Polygala rosmarinifolia Wights \& Arn. Journal of applied pharmaceutical science 2(4): 188-190. https://doi:10.7324/JAPS.2012.2504

7. Al-Gara'awi NI (2019) Analysis of bioactive phytochemical compound of (Cyperus alternifolius L.) By using gas chromatographymass spectrometry. IOP Conf. Series: Materials Science and engineering 571: 1-19. https://doi:10.1088/1757-899X/571/1/012047

8. Al-Marzoqi AH, Hadi MY, Hameed IH (2016) Determination of metabolites products by Cassia angustifolia and evaluate antimicrobial activity. Journal of pharmacognosy and phytotherapy 8(2): 25-48. https://doi:10.5897/JPP2015.0367

9. Anand K, Ziehbuhr J, Wandhwani P, Meters JR, Hilgenfield R (2003) Coronavirus main proteinase (3CL pro) structure: Basis for design of anti-SARS. Sciencexpress 300(5626): 1763-1767. https://doi:10.1126/cience.1085658

10. Andrusier N, Nussinov R,Wolfson HJ (2007) FireDock: Fast iteration refinement in molecular Docking. Proteins 69(1): $139-159$. https://doi:10.1002/prot.21495

11. Ansarali S, Manikandan S, Lakshmanan GMA (2018) Identification of biological components from potential bone healer medicinal plants. Journal of drug delivery and therapeutics 8(3):32-41. https://doi.org/10.22270/jddt.v8i3.1762

12. Aparna V, Dileep VK, Mandal KP, Karthe P, Sadasivan C, Haridas M (2012) Anti-inflammatory property of n-Hexadecanoic acid: structural evidence and kinetic assessment. Chemical biology and drug design 80(3): 434-439. https://doi:10.1111/j.17470285.2012.01418.x

13. Asaraja A, Sahayaraj K (2013) Screening of insecticidal activity of brown macroalgal extracts against Dysdercus cingulatus (Fab.) (Hemiptera: Pyrrhocoridae). Journal of Biopesticides 6(2): 193-203.

14. Autore G, Marzocco S, Palladino C, Saturnino C, Sinicropi S, Spagnuolo A, Vivacqua E, Capasso A (2010) New amides of arachidonic acid as potential anti-inflammatory drugs:A preliminary study. Biomedical research 21(4).

15. Babar AG, Pande A, Kulkarni BG (2016) Anti-fungal activity and investigation of bioactive compounds of marine intertidal bivalve Gafrarium divaricatum from West coast of India. International journal of pure and applied bioascience 4(2): $211-217$. https://doi:10.18782/2320-7051.2273

16. Balamurugan TSB, Gunanithi M, Raja I, Dr. Vinothkumar D, Dr. Ramesh Babu NG, Sumanthi S, Aneesh Nair, Florida Tilton (2017) Antidiabetic potential of various traditional medicinal plants and in silico European journal of biotechnology and bioscience 5(2): $34-$ 40.

17. Balasubramani S, Sabapathi G, Moola AK Solomon RV, Venuvanalingam P, Diana RKB (2018) Evaluation of the leaf essential oil from Artemisia vulgaricus and its larvicidal and repellent activity against dengue fever vector Aedesaegypti- an experimental and molecular docking investigation. American chemical society publication 3: 15657-15665. https://doi:10.1021/acsomega.8b01597

18. Barry OP, Practico D, Lawson JA, FitzGerald GA (1997) Trancellular activation of platelets and endothelial cells by bioactive lipids in platelet microparticles. Journal of Clinical Investigation 99(9): 2118-1227.

19. Bronowska AK (2011) Thermodynamics of ligand-protein interaction. Implication for molecular design thermodynamic-interaction studies-solid, liquid and gases. InTech. Thermodynamics. Edited by Dr. Juan Carlos Moreno pirajajn1-48. https://doi:10.5772/19447

20. Chandrasekar T, Rao KRM, Kumar VR, Prabhu K, Kumar NS, Divya D (2015) GC-MS analysis, antimicrobial, antioxidant activity of an Ayurvedic medicine, Nimbapatradi Choornam. Journal of chemical and pharmaceutical research 7(8): $124-136$.

21. Chauhan S, Sharma, S (2017) Conservation of rare and endangered therapeutically important orchid Pleione maculata (Lindl.) \& Paxton through pseudobulb culture In-vitro. Indian Journal of science resources 15(1): 22-26.

22. Chen C, Tong Z, Liao D, Li Y, Yang G, Li M (2014) Chemical composition and antimicrobial and DPPH scavenging activity of essential oil of Toona sinensis (A. Juss) Roem from China. Bioresources 9(3): 5262-5278.

23. Chidambaram N, Zhou L, Cohen JS (1996) Targeting of antisense: Synthesis of steroid-linked and steroid-bridged oligonucleotides. Drug delivery 3(1), 27-33. https://doi.org/10.3109/10717549609031378

24. Chidambarampillai ST, Mohan VR (2013) GC-MS analysis of bioactive components of aerial parts of Fluggea leucopyrus Willd. (Euphorbiaceae).Journal of applied pharmaceutical science 3(5): 126-130.

25. Daina A, Michielin O, Zoete V (2003) SwissADME: a free web tool to evaluate pharmacokinetics, drug-likeness and medicinal chemistry friendliness of small molecules. Nature scientific reports. https://doi: 10.1038/srep42717

26. Da Silva DLL, Nascimento DSM, Silva SHD, Furlan M, Bolzani SV (2003) Antibacterial activity of a stearic acid derivative from Stemodia foliosa. Planta Medica 68(12): 1137-1139.

27. Darmasiwi S, Indriani V, Innata D, Semiarti E (2015) The potential production of Aromatic Compounds in Flowers of Vanda tricolor. The $5^{\text {th }}$ International conference on Mathematics and Natural Sciences 090006- 1- 090006-4. https://doi:10.1063/1.4930751 
28. Das NU, Madhavi N (2011) Effect of polyunsaturated fatty acids on drug-sensitive and resistant tumor cells in vitro. Lipids in health and disease 10(159):1-35. https://doi:10.1186/1476-511X-10-159

29. De Kock N (2016) Targeted analysis of bioactive steroids and oxycholesterols, Method development and application1-41.

30. De LC, Medhi RP (2015) Orchid-A diversified component of farming systems for profitability and livelihood security of small and marginal farmers. Journal of global biosciences 4(2): 1393-1406.

31. De Sousa DP, Raphael E, Brocksom U (2007) Sedative effect of monoterpene alcohols in mice: A preliminary screening. Zeitschrift fur Naturforschung C, Journal of bioscience 563-566. https://doi:10.1515/znc-2007-7-816

32. Dinesh MD, Carmel A, George N, Ajma N, Anjana JC, Meenatchisundaram S (2016) Terminaliachebula-A potential natural herbal drug against mastitis isolates. IOSR Journal of agriculture and veterinary science 9(10): 64-69.

33. Donald C Hall, Hai-Feng Ji (2020) A search for medications to treat COVID-19 via in silico molecular docking models of the SARS-CoV2 spike glycoprotein and 3CL protease. Travel medicine and infectious diseases. https://doi.org/10.1016/j.tmaid.2020.101646

34. Doss CGP, Chakraborty C, Chen L, Zhu H (2014) Integrating In silico prediction methods, molecular docking and molecular dynamics simulation to predict the impact of ALK Missense mutations in structural perspective. BioMed Research international 2014: 1-15. https://doi.org/10.1155/2014/895831

35. Dreosti IE (1996) Bioactive ingredients: antioxidants and polyphenols in tea. Nutrition reviews 54(11): S51-S58. https://doi.org/10.1111/j.1753-4887.1996.tb03819.x

36. Dua S, Garg N (2013) Biochemical methods of Analysis. Narosa Publishing House. New Delhi.

37. Duhovny D, Nussinov R, Wolfson HJ (2002) Efficient unbound docking of rigid molecules. In R. Guigo and D. Gusfield, editors, workshop on algorithms in bioinformatics. Springer Verlag 2452:185-200. https://doi.org/10.1007/3-540-45784-4_14

38. Easwaran L, Ramani AV (2014) Phytochemical examination and GC-MS studies of the medicinal plant- Naravelia zeylanica. International journal of research and development in pharmacy and life sciences 3(5): 1180-1188.

39. Elaiyaraja A, Chandramohan G (2016) Comparative phytochemical profile of Indoneesiella echioides (L.) Nees leaves using GC-MS. Journal of pharmacognosy and phytochemistry 5(6): 158-171.

40. Elumalai D, Hemalatha P, Kaleena PK (2015) Larvicidal activity and GC-MS analysis of Leucas aspera against Aedes aegypti Anopheles stephensi and Culex quinquefasciatus. Journal of the Saudi society of agricultural sciences 16(4): $306-313$. https://doi.org/10.1016/j.jssas.2015.10.003

41. Eswaraiah G, Peele KA, Krupanidhi S, Kumar BR, Venkateswarulu TC (2020) Identification of bioactive compounds in leaf extract of Avicennia alba by GC-MS analysis and evaluation of its in-vitro anticancer potential against MCF7 and HeLa cell lines. Journal of King Saud University-Science 32(1): 740-744. https://doi.org/10.1016/j.jksus.2018.12.010.

42. Ezekiel A, Zubai S, Abiodun O, Iqbal J (2018) GC-MS analysis and anti-diabetic potentials of Bridelia micrantha crude extracts. Integrative molecular medicine 5(4): 1-5.

43. Gastner T, Krimmer PH (2013) US Patent 8,501,810 B2; 2013. Date of patent- 6 Aug 2013; 1-8.

44. George LO, Radha HR, Somasekariah BV (2018) In vitro anti-diabetic activity and GC-MS analysis of bioactive compounds present in the methanol extract of Kalanchoe pinnata. Indian journal of chemistry 57B: 1213-1221.

45. Ghosal S, Srivastava KA (2013) Fundamentals of Bioanalytical techniques and instrumentation. Raj Press New Delhi $153-154$.

46. Gideon AV (2015) GC-MS analysis of phytochemical components of Pseudoglochidion anamalayanum Gamble: an endangered medicinal tree. Asian Journal of plant science and research 5(12): 36-41.

47. Gopinath S, Sakthidevi G, Muthukumaraswamy S, Mohan VR (2013) GC-MS Analysis of bioactive constitutes of Hypericum mysorense (Hypericaceae) Journal of current chemical and pharmaceutical sciences 3(1): 6-15.

48. Groneberg DA, Hilgenfield R, Zabel P (2005) Molecular mechanism of severe acute respiratory syndrome (SARS). Respiratory research 6(8):1-16. https://doi.org/10.1186/1465-9921-6-8.

49. Gulam M, Ali NK, Kamal MK, Mayur P (2016) Antisense therapy and its application in biopharmaceutical research: past, present and future. Asian pacific journal of pharmaceutical and applied sciences 61-69.

50. Gurnani N, Gupta M, Mehta D, Mehta KB (2015) Chemical composition, total phenolic and flavonoid contents, and in vitro antimicrobial and antioxidant activities of crude extracts from red chilli seeds (Capsicum frutescens). Journal of Taibah University for Science 462- 470. https://doi.org/10.1016/j.jtusci.2015.06.011.

51. Hadi MY, Mohammed GJ, Hameed IH (2015) Analysis of bioactive chemical compounds of Nigella sativa using Gas chromatographymass spectrometry. Journal of pharmacognosy and phytotherapy 8(2): 8-24. https://dx.doi.org/10.5897/JPP2015.0364. 
52. Hamada HM, Awad M, El-Hefny M, Moustafa MAM (2018) Insecticidal activity of garlic (Allium sativum) and ginger (Zingiber officinale) oils on the cotton leaf worm, Spodoptera littoralis (Boisd) (Lepidoptera:Noctuidae). African entomology 18;26(1): 84-94. https://doi.org/10.4001/003.026.0084.

53. Hameed IH, Altameme HJ, Idan SA (2016) Artemisia annua: Bioachemical products analysis of methanolic aerial parts extract and anti-microbial capacity. Research journal of pharmaceutical biological and chemical sciences 7(2):1843-1868.

54. Hussein MH (2016) Analysis of trace heavy metals and volatile chemical compounds of Lepidium sativum using atomic absorption spectroscopy, gas chromatography-mass spectrometric and fourier-transform infared spectroscopy. Research journal of pharmaceutical, biological and chemical sciences 7(4):2529-2555

55. Ingole NS (2016) Phytochemical analysis of leaf extract of Ocimum americanum (Lamiaceae) by GC-MS method. World scientific news 76-87.

56. Iyamah P, Famuti A, Idu M (2017) GC-MS and Molecular docking studies for identification of anti-malarial compounds in PMII-a polyherbal formulation. Chemistry research journal 2(1): 46-56.

57. Jacobson M (1969) Sex Pheromone of the Pink Bollworm Moth:Biological masking by its geometrical isomer. Science 163(3863): 190191. https://doi.org/10.1126/science.163.3863.190

58. Jahan Y, Mahmood T, Bagga P, Kumar A, Singh K, Mujahid M (2015) Future prospects of cough treatment, herbal medicines v/s modern drugs. International Journal of pharmaceutical sciences research 6(9): 1000-1009

59. Javitt NB (1990) 26-Hydroxycholesterol: synthesis, metabolism and biologic acitivities. Journal of Lipid research 31: $1527-1533$.

60. Jialal I, Grundy MS (1992) Effect of dietary supplementation with alpha-tocopherol on the oxidative modification of low density lipoprotein. Journal of Lipid Research 33(6): 899- 906.

61. Jothi SR, Uttayakumari F, Bharathy V (2015) Phytochemical profile of leaf samples of subspecies of Senna italic Mill. Bioscience Discovery 6(2): 106-111.

62. Julsrigival J, Songsak T, Kirdmanee C, Chansakaow S (2013) Determination of volatile constituents of Thai Fragrant orchids by Gas Chromatography-Mass Spectrometry with Solid-Phase Microextraction. Journal of Natural Science 12(1): 43-56.

63. Karthi S, Vinothkumar M, Karthic U, Manigandan V, Saravanan R, Vasantha-Srinivasan P, Kamaraj C, Shivakumar MS, De Mandal S, Velusamy A, Krutmuang P, Senthil-Nathan S (2020) Biological effects of Avicennia marina (Forssk.) Vierh. Extractson physiological, biochemical, and anti-microbial activitiesagainst three challenging mosquito vectors and microbial pathogens. Environmental Science Pollution Research. https://doi.org/10.1007/s11356-020-08055-1.

64. Karunanithi A, Venkatachalam S (2019) Optimization of ultrasound-assisted extraction of phenolic compounds from wood apple pulp: identification of phytochemical using GC-MS. Chemical industry and chemical engineering quarterly 25 (4):361-368.

65. Khalil MN, Shalaby AE, Ali AIMD, Ali ME, Aboul-Enein MA (2014) Biological activities of secondary metabolites from Emericella nidulans EGCU 312. African Journal of Microbiology Research 8(20): 2011- 2021. https://doi.org/10.5897/AJMR2014.6827.

66. Khan K, Firdous S, Ahmad A. Muhammad N, Rasheed M, Faizi S (2016) GC-MS profile of antimicrobial and antioxidant fractions from Cordia rothii Pharmaceutical biology 54(11): 2597-2605. https://doi.org/10.3109/13880209.2016.1172320.

67. Kim SS, Kim JE, Hyun CGu, Lee NH (2011) Neolitsea aciculate essential oil inhibits drug-resistant skin pathogen growth and Propionibacterium acnes-induced inflammatory effects on human monocyte leukemia. Natural product communication 6(8): 11931198.

68. Kim TK, Chen J, Li W, Zjawiony J, Miller D, Janjetovic Z, Tuckey RC, Slominski A (2009) A new steroidal 5,7-diene derivative, 3-betahydroxyandrosta-5,7-diene-17beta-carboxylic acid, shows potent anti-proliferative activity 75(3): 230-239. https://doi.org/10.1016/j.steroids.2009.12.004.

69. Kondo S, Mamada A, Yamaguchi J, Fukuro S (1990) Protective effect of DL-alpha-tocopherol on the cytotoxicity of ultraviolet B against human skin fibroblasts in vitro. Europe PMC 7(4): 173-177.

70. Kumar D, Arora S, Verma A (2013) Fatty acid composition and antimicrobial and antioxidant activity of Cassla glauca seed extracts. International Journal of Phytopharmacology 4(2): 113-118.

71. Kumar M, Kumar D, Raj V (2017) Studies on Imidazole and its derivatives with particular emphasis on their chemical/biological applications as bioactive molecules intermediated to bioactive molecules. Current synthetic and systems biology 5(1): 1-10. https://doi.org/10.4172/2332-0737.1000135.

72. Kumar NN, Ramakrishnaiah H, Krishna V, Deepalakshmi PA (2015) GC-MS Analysis and antimicrobial activity of seed oil of Broussonetia papyrifera (L) Vent. International Journal of Pharmaceutical sciences and Research 6: 3954- 3960. 
73. Kumar PP, Kumaravel S, Lalitha C (2010) Screening of antioxidant activity, total phenolic s and GC-MS study of Vitex negundo. African Journal of Biochemistry Research 4(7): 191-195.

74. Kumar R, Deka CB, Roy RA (2012) Evaluation of orchid species under sub-tropical mid-hills of Meghalaya. HortFlora. Research Spectrum 1(1): 24-28.

75. Kumaravel S, Bhabh PK, Singaravadivel K (2016) GC-MS and FT-IR analysis of the spice ajwain (Trachyspermum ammi). International journal of modern research and reviews 4(3): 1114-1120.

76. Kumaravel S, Muthukumaran P, Thomas N (2019) Phytochemical, GC-MS and FT-IR analysis of Papver somniferum L. Journal of pharmaceutical and biological sciences 7(1): 1-8.

77. Lakshmi VTP, Rajalakshmi P (2011) Identification of phyto-components and its biological activities of Aloe vera through the Gas Chromatography- Mass Spectrometry. International Research Journal of Pharmacy 2(5): 247- 249.

78. Lalithi S, Parthipan B, Mohan VR (2015) Determination of bioactive components of Psychotria nilgiriensis Deb \& Gang (Rubiaceae) by GC-MS Analysis. International Journal of pharmacognosy and phytochemical research 7(4): 802-809.

79. Lawal B, Shittu OK, AbdulRasheed-Adeleke T, Ossai PC, Ibrahim AM (2015) Determination of bioactive constituents of giant african snail (Archachatina maginata) Haemolymph. Journal of Pharmacy and Biological Sciences 10(2): 59-64.

80. Li Fang (2016) Strcuture, function, and evolution of Coronavirus spike protein. Annu ReV Virol. HHS Public access 3(1): $237-261$. https://doi.org/10.1146/annurev-virology-110615-042301

81. Lindley, Paxton (1851) Pleione maculata. Flora of China 25: 326-327. http://www.efloras.org/florataxon.aspx? flora_id=2\&taxon_id=242424455.

82. Lipinski CA, Lombardo F, Dominy BW, Feeny PJ (1997) Experimental and computational approaches to estimate solubility and permeability in drug discovery and development setting. Advance drug delivery reviews. 1997; 23(1-3):3-25. doi.org/10.1016/S0169409X(96)00423-1

83. Mashiach E, Schneidman-Duhovny D, Andruisier N, Nussinov R, Wolfson HJ (2008) FireDock: a web server for fast interaction refinement in molecular docking. Nucleic Acids Research 36: w229-w232. https://dx.doi.org/10.1093/nar/gkn186.

84. Mishra Shweta, Dahima Rashmi (2019) In-vitro ADME studies of TUG-891, a GPR-120 inhibitor using Swiss ADME. Journal of drug delivery and therapeutics 9(2): 266-369. https://doi.org/10.22270/jddt.v9i2-s.2710

85. Mohammad H, Prabhu K, Rao MRK, Sundram L, Dinakar S, Kumar MS, Vijayalakshmi N (2019) The gas chromatography-mass spectrometry study of one Ayurvedic pain relieving oil 'Karpooradi Thailam'. Drug invention today 12(7): 1542-1546.

86. Muthukrishnan S, Thinakaran R (2012) Chemical investigation of Pseudarthria viscida root by GC-MS analysis. Pharmacognosy communications 2(3): 26-29. https// doi.org/5530/pc.2012.3.6

87. Naidu RJ, Ismail BR, Yeng C, Sasidharan S, Kumar P (2012) Chemical composition and antioxidant activity of the crude methanolic extracts of Mentha spicata. Journal of physiology 4(1): 13-18.

88. Oduje AA, Awode A, Edah A, Sagay I (2015) Characterization and phytochemical screening of Hexane oil extract from Cissus aralioides seeds. International Journal of scientific and engineering research 6(1):112-116.

89. Okereke SC, ljeh II, Arunsi UO (2017) Determination of bioactive constituents of Rauwolfia vomitoria Afzel (Asofeyeje) roots using gas chromatography-mass spectrometry (GC-MS) and Fourier transform infrared spectrometry (FT-IR). Asian Journal of Pharmacy and Pharmacology 11(2): 25-31. https://doi.org/10.5897/AJPP2016.4712.

90. Otaibi AA, McCluskey A (2013) Multicomponent reactions in lonic liquids. IMTECH. Chapter-18, lonic Liquids-New aspects for the future 458-498.

91. Qurzeddine W, Fadel H, Mechehoud Y, Chalchat JC, Figueredo G, Chalard P, Benayache F, Benayache S (2017) Chemical composition and antioxidant activity of the fruit essential oil of Zizyphus lotus (L.) Desf. (Rhamanaceae). International Journal of Pharmacognosy and Phytochemical Research 9(2): 228-232.

92. Padma M, Ganesan S, Jayaseelan T, Azhagumadhavan S, Sasikala P, Senthikumar S, Mani P (2018) Phytochemical screening and GCMS analysis of bioactive compounds present in ethanolic leaves extract of Silybum marianum (L). Journal of drug delivery and therapeutics 9(1): 85-89.

93. Palakkal L, Hukuman NHZ, Mullapally J (2017) Anti-oxidant activities and chemical composition of various crude extracts of Lepidagathis keralensis. Journal of applied pharmaceutical science 7(6). 182-189. https//doi.org/10.7324/JAPS.2017.7062.

94. Pant B (2003) Medicinal orchids and their uses: Tissue culture a potential alternative for conservation. African Journal of Plant Science 7(10): 445- 467. https//doi.org/ 10.5897/AJPS2013.1031. 
95. Pantsar T, Poso A (2018) Binding affinity via docking: Fast and fiction. Molecules 23(1899): 1-11. https://dx.doi.org/10.3390/molecules23081899.

96. Paulpriya K, Tresina PS, Mohan VR (2014) Assessment of bioactive constituents by GC-MS of Crotalaria longipes Wight \& Arn: An endemic plant. International journal of pharmacognosy and phytochemical research 6(4): 1043-1048.

97. Pereira DM, Correia-da-silva G, Valentao P, Teixeira N, Andrade PB (2014) Anti-inflammatory effect of unsaturated fatty acid acids and Ergosta-7,22-dien-3-ol from Marthasterias glacialis. Prevention of CHOP-Mediated ER-stress and NF-kB activation. PLoS ONE 9(2):e88341. https://doi.org/10.1371/journal.pone.0088341

98. Pinto AEM, Araujo GS, Morais IM, Sa PN, Lima MC, Rosa AC, Siqueira PE, Johann S, Lima SRAL (2017) Antifungal and antioxidant activity of fatty acid methyl esters from vegetable oils. Annals of the Brazilian Academy of Sciences 89(3):1671-1681. https//doi.org/10.1590/0001-376520172016090.

99. Plainfosse H, Burger P, Azoulay S, Landreau A, Verger-dubois G, Xavier Fernandez (2017) Development of a natural-age ingredient based on Quercus pubescens wild. Leaves extract-A case study. Cosmetics 1(15): 1-22. https://doi.org/10.3390/cosmetics5010015

100. Prabhadevi V, Sathish S, Johnson M, Venkatramani B, Janakiraman N (2012) Phytochemical studies on Allamanda cathartica L. using GC-MS. Asian pacific journal of tropical medicine S550-S554.

101. Prabhu DS, Rajeswari VD (2016) In silico docking analysis of bioactive compounds from chinese medicine Jinqi Jiangtang Tablet (JQJTT) using Patch Dock. Journal of chemical and pharmaceutical Research 8(5): 15-21.

102. Qamar MTU, Alqahtani SM, Alamri MA, Chen LL (2020) Structural basis of SARS-CoV-2 3CLpro and anti-COVID-19 drug discovery from medicinal plants. Journal of pharmaceutical analysis. 2020; Doi:https://doi.org/10.1016/j.jpha.2020.03.009

103. Rajalakshmi K, Mohan VR (2016) Determination of Bioactive components of Myxopyrum serratulum W. HILL (Oleaceae) stem by GCMS analysis. International research journal of pharmacy 38(1). article no 6: 30-35

104. Rajashyamala G, Elango V (2015) Identification of bioactive components and its biological activities of Evolvulus alsinoides A GC-MS study. International Journal of chemical studies 3(1): 41-44

105. Rajendra P, Bharathidasan R, Sureshkumar K (2017) GC-MS analysis of phyto-components in raw and treated sugarcane juice. International Journal of Current Microbiology and Applied Science 6(7): 51-61. http://dx.doi.org/10.20546/ijcmas.2016.501.007.

106. Rajeswari G, Murugan M, Mohan RV (2013) GC-MS analysis of bioactive components of Hugonia mystax bark (Linaceae). Journal of pharmaceutical and Biomedical Sciences 29(29): 818-824.

107. Rane JS, Chatterjee A, Kumar A, Ray S (2020) Targeting SARS-CoV-2 spike protein of COVID-19 with naturally occurring phytochemicals: an In silico study for drug development ChemRxiv.doi.org/10.26434/chemrxiv.12094203.v1

108. Rautela I, Sharma MD, Sharma N, Kishor K, Singh K, Sharma N (2018) Comparative GC-MS analysis of leaf and root extract of medicinal plant Withania somnifera. World journal of pharmaceutical research 7(2): 956-972.

109. Ren R, Hashimoto T, Mizuno M, Takigawa H, Yoshida M, Azuma T, Kanazawa K (2013) A lipid peroxidation product 9-oxononanoic acid induces phospholipase A2 activity and thromboxane A2 production in human blood. Journal of Clinical Biochemistry and Nutrition 52(3): 228-233. https://doi.org/10.3164/jcbn.12-110.

110. Sadler JJ, Smith MJ, Zettler WL, Alborn TH, Richardson WL (2011) Fragrance composition of Dendrophylax lindenii (Orchidaceae) using a novel technique applied in situ. European Journal of Environmental Sciences 1(2): 137-141. https://doi.org/10.14712/23361964.2015.56.

111. Saeidnia S, Manayi A, Gohari AR. Abdollahi M (2014) The story of Beta-sitosterol-Areview. European journal of medicinal plants 4(5): 590-609. https://doi.org/10.9734/EJMP/2014/7764.

112. Sahin N, Kula I, Erdogan Y (2006) Investigation of antimicrobial activities of nonanoic acid derivatives. Fresenius Environmental Bulletin 15(2): 141-143.

113. Sardar R, Satish D, Birla S, Gupta D (2020) Comaprative analyses of SARS-CoV2 genomes from different geographical locations and other coronavirus family genomes reveals unique features potentially consequential to host-virus interaction and pathogenesis BioRxiv preprint. https://doi.org/10.1101/2020.03.21.001586

114. Sathiyabalan B, Packia LM, Muthukumarasamy S, Mohan VR (2014) GC-MS Analysis of bioactive components of Petiveria alliacea whole plant (Phytolaccaceae). International Journal of Pharma Research and Health Sciences 2(5): $387-392$.

115. Saxena M, Faridi U, Srivastava SK, Darokar MP, Mishra R, Pal A, Shisodia B, Khanuja SPS (2007) A cytotoxic and Hepatoprotective agent from Withania somifera and biological evaluation of its Ester derivatives. Natural product Communications 2(7): 775-778. https://doi.org/10.1177\%2F1934578X0700200714. 
116. Schneidman-Duhovny D, Inbar Y, Nussinov R, Wolfson HJ (2005) PatchDock and SymmDock: servers for rigid and symmetric docking. Nucleic Acids Research 33: W363-367. https://dx.doi.org/10.1093/nar/gki481.

117. Selvan PS, Velavan S (2015) Analysis of bioactive compounds in methanol extracts of Cissus vitiginea leaf using GC-MS technique. Rasayan J. Chem 8(4): 443-447.

118. Sharad S (2019) Antisense therapy: an overview. Henry Jackson foundation for the advancement of military medicine, Bethesda, Maryland, USA. Intechopen.

119. Sharma V, Chitranshi N, Agarwal AK (2014) Significance and biological importance of pyrimidine in the microbial world. International journal of medicinal chemistry 2014: 1-31. https://doi.org/10.1155/2014/202784.

120. Shen M, Zhou Y, Ye J, Al-maskri AAA, Kang Y, Zeng S, Cai S (2020) Recent advances and perspectives of nucleic acid detection for coronavirus. Journal of pharmaceutical analysis 97-101. https://doi.org/10.1016/j.jpha.2020.02.010.

121. Shree LR (2012) Efficacy of supplementation of flaxseed and soybean on post-operative cancer patients. Thassim Beevi Abdul Kader College for Women. Chennai 116-121.

122. Singh AK (2016) Structure, synthesis and application of nanoparticles. Chapter-2. Engineered nanoparticles. Structure, properties and mechanisms of toxicity 19-76.

123. Singh K, Kaur T (2016) Pyrimidine-based antimalarials: design stragtegies and antiplasmodial effects. MedChemComm. https://doi.org/10.1039/C6MD00084C.

124. Singh S, Srivastava HK, Kishor G, Singh H, Agrawal P, Raghava GPS (2017) Evaluation of protein-ligand docking methods on peptideligand complexes for docking small ligands to peptides. BioRxiv. https://doi.org/10.1101/212514

125. Subavathy P, Thilaga RD (2016) GC-MS analysis of bioactive compounds from whole body tissue methanolic extract of Cypraea Arabica (L.1758). World journal of pharmaceutical research 5(3): 800-806.

126. Suffo AKL, Ashish R, Tedonkeng PE, Kuiate JR (2016) Effect of processing methods on chemical composition and antioxidant activities of two Amaranthus Harvested in West Region of Cameroons. Journal of nutrition and food sciences 6(2):1-9.

127. Sujatha K, Vijayalakshmi V (2013) Foliar application of Caulerpa racemosa seaweed extract as bio-stimulant for enhancement of growth and yield of blackgram (Vigna mungo ). International Journal of Advancements in Research and Technology 2(10): 216-230.

128. Sujatha, Karthika, Sivakamasundari, Mariajancyrani, Chandramohan (2014) GC-MS analysis of phytocomponents and total antioxidant activity of hexane extract of Sinapis alba. International journal of pharmaceutical, chemical and biological sciences 4(1): 112117.

129. Sulthanabegam M, Palani S, Senthikumar B (2019) Phytoconstituents screening by GC-MS and evaluation of In-vitro Gastroprotective and antioxidant activity of Vulva lactuca. International Journal of pharmacy and biological sciences 9(2): 939-950.

130. Surana P, Singh S, Manokaran S, Reddy AHM (2018) The interactions between variants of GALT in Galactosemia: In silico approach. International journal of fundamental and applied sciences 7(3): 14-18.

131. Suzuki K, Shimizu T, Nakata T (1998)The cholesterol metabolite cholest-4-en-3one and its-oxo derivatives suppress body weight gain, body fat accumulation and serum lipid concentration in mice. Bioorganic and Medicinal Chemistry Letters 8(16): 2133-2138. https://doi.org/10.1016/S0960-894X(98)00362-X.

132. Suzuki K (1993) Anti-obesity effect of cholest-4-en-3-one, an intestinal catabolite of cholesterol, on mice. Journal of Nutritional Science and Vitaminology (Tokyo) 39(5):537-543. https://doi.org/10.3177/jnsv.39.537.

133. Sympli HD, Paul S, Borah VV, Choudhury M (2019) Phytochemical and anti-bacterial activity of an endangered orchid, Pleione maculata (Orchidaceae) of Meghalaya. International journal of research and analytical reviews 6(2): 221-232. http//doi.org/10.1729/Journal.21437.

134. Teoh ES (2016) Orchids of Asia. Times Editions/Marshall Cavendish Singapoore 367.

135. Thomas E, Aneesh TP, Thomas DG, Anandan R (2013) GC-MS analysis of phytochemical compounds present in the rhizomes of Nervilia aragoana Asian Journal of pharmaceutical and clinical research 6(3): 68-74.

136. Tian S, Hu W, Niu Li, Lui H, Xu H, Xiao S (2020) Pulmonary pathology of early-phase 2019 Novel Coronavirus (COVID-19) Pneumonia in two patients with lung cancer. Journal of Thoracic Oncology 1-5.

137. Tufino C, Bernal C, Ottone C, Romero O, Illanes A, Wilson L (2019) Synthesis with immobilized lipases and downstream processing of Ascorbyl palmitate. Molecules 24(3227): 1-13. https://dx.doi.org/10.3390/molecules24183227.

138. Tyagi T, Agarwal M (2016) Phytochemical screening and GC-MS analysis of bioactive constituents in the ethanolic extract of Pista stratiotes and Eichhornia crassipes (Mart.) solms. Journal of Pharmacognosy and phytochemistry 6(1): 195-206. 
139. Ukil S, Laskar S, Roy NR (2015) Physicochemical characterization and antibacterial activity of the leaf oil of Crotalaria pallida Journal of Taibah University for Science 490- 496. https://doi.org/10.1016/j.jtusci.2015.07.001.

140. Umaiyambigai D, Saravanakumar K, Raj AG (2017) Phytochemical profile and antifungal activity of leaves methanol extract from the Psydrax dicoccos (Gaertn) Teys. \& Binn. Rubiaceace family. International Journal of pharmacology, phytochemistry and ethnomedicine 7: 53-6. https://doi.org/10.18052/www.scipress.com/IJPPE.7.53.

141. Upgade A, Bhaskar A (2013) Characterization and medicinal importance of phytoconstituents of papaya from down South Indian region using Gas Chromatography and Mass Spectroscopy. Asian Journal of pharmaceutical and Clinical Research 6(4): $101-106$.

142. Valiei M, Shafaghat A, Salimi F (2011) Chemical composition and antimicrobial activity of the flower and root hexane extracts of Althaea officinalis in Northwest Iran. Journal of medicinal plants research 5(32): 6972-6976. https://.doi.org/10.5897/FJMPR11.963.

143. Vardanyan RS, Hruby VJ (2006) Chapter-17. Digitoxin.Synthesis of essential drug. Cardiotonic drugs 237-243.

144. Vijayakumari J, Raj TLS (2019) GC-MS analysis of secondary metabolites from acetone and chloroform extract of Dicranopteris linearis (burm.F.) Underw. International research journal of biological sciences 8(9): 39-43.

145. Vijisaral ED, Arumugam S (2014) GC-MS analysis of bioactive constituents of Indigofera suffruticosa Journal of Chemical and Pharmaceutical Research 6(8): 294- 300

146. Wang L, Wang Y, Ye D, Liu Q (2020) Review of the 2019 novel corona-virus (SARS-CoV-2) based on current evidence. International journal of antimicrobial agent 105948: 1-7. https://doi.org/10.1016/j.ijantimicag. 2020

147. Wei SL, Wee W, Siong FYJ. Syamsumir FD (2011) Characterization of antimicrobial, antioxidant, anticancer property and chemical composition of Michelia champaca seed and flower extract. Stamford Journal of Pharmaceutical Sciences 4(1): 19-24. https//doi.org/10.3329/sjps.v4i1.886.

148. Wen C, Shyur L, Jan J, Liang P, Kuo C, Arulselvan P, Wu J, Yang N (2011) Traditional chineses medicine herbal extracts of Cibotium barometz, Gentiana scabra, Dioscorea batatas, Cassia tora, and Taxillus chinensis inhibit SARS-COV replication. Journal of traditional and complementary medicine 1(1): 41-50. https://doi.org/10.1016/s2225-4110(16)30055-4.

149. World Health Organization (WHO) (2018) Critical review report: Pregabalin. Expert committee on Drug Dependence forty-first meeting, Geneva, 12-16 November 2018: 1-33.

150. Wu D, Wu T, Liu Q, Yang Z (2020) The SARS-CoV-2 outbreak: what we know. International journal of infectious disease 44-48. https://doi.org/10.1016/j.ijid.2020.03.004

151. Wu Q, Zhou L, Sun X, Yan Z, Hu C, Wu J, Xu L, Li X, Liu H, Yin P, Zhao J, Li Y, Wang X, Li Y, Zhang Q, Xu G, CH (2017) Altered lipid metabolism in recovered SARS patients twelve years after infection. Scientific report 7: 1-12. https://doi.org/10.1038/s41598-01709536-z.

152. Yadav S, Pandey SK, Singh VK, Goel Y, Kumar A, Singh SM (2017) Molecular docking studies of 3-bromopyruvate and its derivaties to metabolic regaltory enzymes: Implication in deisgning of novel anti-cancer therapeutic strategies. Plos one. 2017; 1-15. https://doi.org/10.1371/journal.pone.0176403.g005

153. Yang P, Wang X (2020) COVID-19: a new challenge for human beings. Cellular and molecular Immunology 1-3.

154. Yang Y, Islam MS, Wang J, Li Y, Chen X (2020) Traditional Chinese medicine in the treatment of patients infected with 2019-New Coronavirus (SARS-CoV-2): A review and perspective. International journal of biological sciences 16(10): 1708-1717. https://dx.doi.org/10.715/ijbs.45538.

155. Yusufzai SK, Khan MS, Hanry EL, Rafatullah M, Elison BB (2019) GC-MS analysis of chemical constituents and in-vitro antioxidant activity of the organic extracts from the stem of Bridelia stipularis. Sans malaysiana 48(5): 999-1009. https://doi.org/10.17576/JSM2019-4805-08.

156. Yuvaraj N, Arul V (2014) In vitro anti-tumor, anti-inflammatory, anti-oxidant, and antibacterial activities of marine brown alga Sargassum wightii collected from Gulf of Mannar. Global Journal of Pharmacology 8(4): 566-577. https//doi.org/10.5829/idosi.gjp.2014.8.4.84281.

157. Zafar MZ (2016) A case study: Pnuemonia. Occupational medicine and health affairs 4(4): 1-3.

158. Zaini RG, Brandt K, Clench MR, Le Maire CL (2012) Effects of bioactive compounds from carrots (Daucus carota L.), Polyacetylenes, Beta-carotene and Lutein on human lymphoid leukaemia cells. Anti-cancer agents in medicinal chemistry 12(0):1-13. https://doi.org/10.2174/187152012800617704

159. Zhang C, Vasmatzis G, Cornette JL, DeLisi C (1997) Determination of atomic desolvation energies from the structures of crystallized proteins. Journal of Molecular Biology 267(3):707-726. https://doi.org/10.1006/jmbi.1996.0859 
160. Zhang H, Penninger JM, Li Y, Zhong N, Slutsky AS (2020) Angiotensin-converting enzyme 2 (ACE2) as a SARS-CoV-2 receptor: molecular mechanisms and potential therapeutic target. Intensive care Med 46: 586-590.

161. Zhang J, Sun H, Chen H, Chen S, Li Zeng, Wang T (2017) Anti-fungal activity, mechanism studies on a- Phellandrene and nonanal against Penicillium cyclopium. Botanical studies 58(13): 1-9. https://dx.doi.org/10.1186\%2Fs40529-017-0168-8

162. Zhang Z, Wu WY, Hou JJ, Zhang LL, Li FF, Gao L, Wu XD, Shi JY, Zhang R, Long HI, Lei M, Wu WY, Guo DA, Chen KX, Hofman LA, Ci ZH (2020) Active constituents and mechanisms of respiratory detox shot, a traditional chinese medidine prescription, for COVID-19 control and prevention: Network-molecular docking LC-MS analysis. Journal of integrative medicine 1-13. https://doi.org/10.1016/j.joim.2020.03.00

\section{Tables}

Table 1 GC-MS analysis of acetone extracts of Pleione maculata 


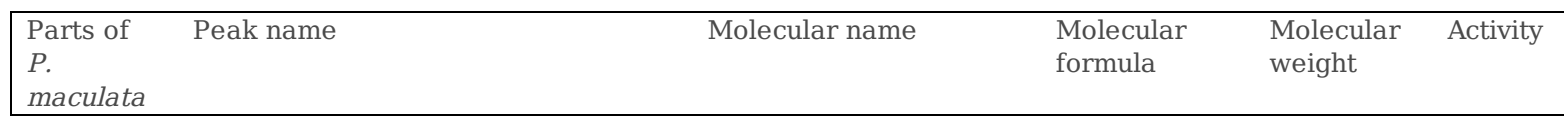

Leave

N-hexadecanoic acid

Palmitic acid

$\mathrm{C}_{16} \mathrm{H}_{32} \mathrm{O}_{2}$

256

Anti-inflammatory, Antioxidant, hypocholesterolemic nematicide, pesticide, anti-androgenic flavor, hemolytic, 5-alpha reductase inhibitor

Anti-carcinogenic (Aparna et al. 2012; Kumar et al. 2010; Shree 2012)

\begin{tabular}{lrr}
\hline Dodecanoic acid & $\mathrm{C}_{12} \mathrm{H}_{24} \mathrm{O}_{2}$ & $\begin{array}{c}200 \\
\text { antibacterial, } \\
\text { antioxidant, } \\
\text { hypercholesterolemic }\end{array}$ \\
(Gideon 2015) &
\end{tabular}

\begin{tabular}{|c|c|c|c|c|}
\hline $\begin{array}{l}\begin{array}{l}\text { 3-L- (+) Ascorbic } \\
\text { dihexadecanoate }\end{array} \\
\text { did }\end{array}$ & & $\mathrm{C}_{38} \mathrm{H}_{68} \mathrm{O}_{8}$ & 652 & $\begin{array}{l}\text { Anti-tumour and antibacterial } \\
\text { activity (Babar et al. 2016) }\end{array}$ \\
\hline $\begin{array}{l}\text { 8,11,14 Eicosatrienoic acid, Methyl } \\
\text { ester }\end{array}$ & $\begin{array}{l}\text { Methyl dihomo- } \gamma- \\
\text { linoleic acid }\end{array}$ & $\mathrm{C}_{21} \mathrm{H}_{36} \mathrm{O}_{2}$ & 320 & $\begin{array}{l}\text { Tumoricidal (Das and Madhavi } \\
\text { 2011) }\end{array}$ \\
\hline $\begin{array}{l}\text { 8, 11, 14-Docosatreienoic acid, } \\
\text { Methyl ester }\end{array}$ & & $\mathrm{C}_{23} \mathrm{H}_{20} \mathrm{O}_{2}$ & & $\begin{array}{l}\text { Anti-diabetic activity (George et al. } \\
\text { 2018) }\end{array}$ \\
\hline Z,Z,-4,6-Nonadecadien-1-ol-acetate & Esters & $\mathrm{C}_{21} \mathrm{H}_{38} \mathrm{O}_{2}$ & 322 & $\begin{array}{l}\text { Insecticidal activity (Hamada et al. } \\
\text { 2018) }\end{array}$ \\
\hline $\begin{array}{l}\text { Dichloroacetic acid, Tridec-2-YNYL } \\
\text { ester }\end{array}$ & & $\mathrm{C}_{15} \mathrm{H}_{24} \mathrm{C}_{12} \mathrm{O}_{2}$ & 306 & Anti-mastitis (Dinesh et al. 2016) \\
\hline Octadecanoic acid, Methyl ester & Methyl stearate & $\mathrm{C}_{19} \mathrm{H}_{38} \mathrm{O}_{2}$ & 298 & $\begin{array}{l}\text { Antifungal and antioxidant (Pinto et } \\
\text { al. 2017) }\end{array}$ \\
\hline $\begin{array}{l}\text { Nonanoic acid, } 9(3- \\
\text { hexemyldenecycyclopropylidene)-,2- } \\
\text { hydroxy-1-1(HYD) }\end{array}$ & $\begin{array}{l}\text { Nonanoic } \\
\text { derivative }\end{array}$ & & & $\begin{array}{l}\text { Not reported } \\
\text { usually nonanoic acid have } \\
\text { nematicidal activity } \\
\text { components of biodegradable } \\
\text { polyesters (Sahin et al. 2006) }\end{array}$ \\
\hline $\begin{array}{l}\text { 9,12,15-Octadecatrienoic } \quad \text { acid, } \\
(\mathrm{Z}, \mathrm{Z}, \mathrm{Z})-\end{array}$ & Linoleic acid & $\mathrm{C}_{18} \mathrm{H}_{30} \mathrm{O}_{2}$ & 278 & $\begin{array}{l}\text { Anti-inflammatory, antihistaminic, } \\
\text { cancer preventive, anti-acne, anti- } \\
\text { coronory (Kumar et al. 2010) }\end{array}$ \\
\hline Octadecanoic acid & Stearic acid & $\mathrm{C}_{18} \mathrm{H}_{36} \mathrm{O}_{2}$ & 284 & $\begin{array}{lr}\text { Hypocholesterolemic, } & \text { surfactant } \\
\text { and softening agent, perfumery, } \\
\text { flavor and in cosmetic } & \\
\text { Antibacterial } & \text { activity } \\
\text { (Rajashyamala and } & \text { Elango } \\
\text { 2015; Da Silva et al. 2003) } & \end{array}$ \\
\hline Docosanoic acid/ Behenic acid & Fatty acid & $\mathrm{C}_{23} \mathrm{SH}_{44} \mathrm{O}_{2}$ & 340 & $\begin{array}{l}\text { Anti-cancer potential against MCF7 } \\
\text { and HeLa cell lines, } \\
\text { Hair moisturizer (Lawal et al. } \\
\text { 2015; Eswaraiah et al. 2020) }\end{array}$ \\
\hline Alpha-Ketostearic acid, ethyl ester & & $\mathrm{C}_{20} \mathrm{H}_{38} \mathrm{O}_{3}$ & 326 & No activity reported \\
\hline $\begin{array}{l}\text { Cyclopropaneoctanoic acid, 2-[[2- } \\
\text { Ethylcyclopropyl) Methyl]cyclo }\end{array}$ & - & $\mathrm{C}_{22} \mathrm{H}_{38} \mathrm{O}_{2}$ & 334 & Anti-carcinogenic (Shree 2012) \\
\hline $\begin{array}{l}\text { 1-naphthaleneproponal, alpha-ethyl } \\
\text { Decahydro-5-(hydroxymethyl)- }\end{array}$ & & $\mathrm{C}_{20} \mathrm{H}_{36} \mathrm{O}_{2}$ & 308 & No activity reported \\
\hline Terpin hydrate & & $\mathrm{C}_{10} \mathrm{H}_{22} \mathrm{O}_{3}$ & 172 & $\begin{array}{l}\text { Expectorant commonly used to } \\
\text { loosen mucus in patients } \\
\text { presenting with acute or chronic } \\
\text { bronchitis and related conditions } \\
\text { (Jahan et al. 2015) }\end{array}$ \\
\hline $\begin{array}{l}\text { Cis, Cis, } \\
\text { Hexadecatrienal }\end{array}$ & aldehyde & $\mathrm{C}_{16} \mathrm{H}_{26} \mathrm{O}$ & 234 & $\begin{array}{l}\text { No activity reported (Prabhadevi et } \\
\text { al. 2012; Abdulaziz et al. 2019) }\end{array}$ \\
\hline Cholest-4-en-3-one & Cholestenone & $\mathrm{C}_{27} \mathrm{H}_{44} \mathrm{O}$ & 384 & $\begin{array}{l}\text { Anti-obesity, suppress body weight } \\
\text { and body fat accumulation (Suzuki } \\
1993,1998 \text { ) }\end{array}$ \\
\hline Diazoprogesterone & $\begin{array}{l}\text { Steroid, } \\
\text { compound }\end{array}$ & $\mathrm{C}_{21} \mathrm{H}_{30} \mathrm{~N}_{4}$ & 338 & $\begin{array}{l}\text { Antimicrobial } \\
\text { anti-inflammatory, } \\
\text { Hepatoprotective, Duiretic, Anti- } \\
\text { cancer } \\
\text { Anti-HIV (Gopinath et al. } \\
\text { 2013; Jothi et al. 2015) }\end{array}$ \\
\hline 26-hydroxy cholesterol & steroid compound & $\mathrm{C}_{27} \mathrm{H}_{46} \mathrm{O}_{2}$ & 402 & $\begin{array}{l}\text { Biomarkers in diagnosis of } \\
\text { Alzheimers disease }(\mathrm{AD}) \text { and other } \\
\text { neurodegenerative disorders (De } \\
\text { Kock 2016) }\end{array}$ \\
\hline $\begin{array}{l}\text { pregn-4-ene-1,20-Dione, 12-hydroxy- } \\
\text { 16,17-dimethyl- }\end{array}$ & Steroid compound & $\mathrm{C}_{23} \mathrm{H}_{34} \mathrm{O}_{3}$ & 358 & $\begin{array}{l}\text { Sexual disorders, baldness, anti- } \\
\text { psioriatic, anti-pyretic, anti-allergic } \\
\text { (Ansarali et al. 2018) }\end{array}$ \\
\hline
\end{tabular}


Spiro[Androst-5-ene-17,15cyclobutan]-2!-one,3-hydroxy-, (3,beta,17,beta)
$\mathrm{C}_{22} \mathrm{H}_{32} \mathrm{O}_{2}$

328
Anti-inflammatory

microbial

Antiarthritic,

antiasthma, 2017)

\begin{tabular}{|c|c|c|c|}
\hline Andrographolide & Diterpenoid & $\mathrm{C}_{20} \mathrm{H}_{30} \mathrm{O}_{5}$ & 350 \\
\hline $\begin{array}{lr}\text { 8-oxatetracyclo } & \{5.2 .1 .1(2,6) . \\
\text { 1(4,10)\}Dodecane, } & \text { 7-tert-Butyl-1, } \\
\text { 9,9-Trimeth } & \\
\end{array}$ & & & 262 \\
\hline Ergosta-7,22-dien-3-ol,(3.Beta, 22E) & & $\mathrm{C}_{28} \mathrm{H}_{46} \mathrm{O}$ & 398 \\
\hline Stigmastan-6,22-dien,3,5-dedihydro & & $\mathrm{C}_{29} \mathrm{H}_{46}$ & 394 \\
\hline $\begin{array}{l}\text { Cholest-5-en-3- } \\
\text { ol(3,beta)-,carbonochloridate }\end{array}$ & & $\mathrm{C}_{28} \mathrm{H}_{45} \mathrm{CIO}_{2}$ & 448 \\
\hline \multicolumn{4}{|l|}{ Cholesterol Isocaproate } \\
\hline Octadecane,3-ethyl-5-(2-ethylbutyl)- & & $\mathrm{C}_{26} \mathrm{H}_{54}$ & 366 \\
\hline \multicolumn{4}{|l|}{ Docosane, 2,4-Dimethyl } \\
\hline DL-alpha-tocopherol & Vitamin E & $\mathrm{C}_{29} \mathrm{H}_{50} \mathrm{O}_{2}$ & 430 \\
\hline
\end{tabular}
2015) et al. 2014)

Antimicrobial 2013) 2016)
Vitamin E

$\mathrm{C}_{29} \mathrm{H}_{50} \mathrm{O}_{2}$ cell signaling, Immunomodulator, used in stroke (Selvan and Velavan

compound not reported

Anti-inflammatory effect (Pereira

Antiasthma, Anti-inflammatory Diuretic, Anticancer, Antiarthritic Antioxidant, insecticidal activity (Sujatha and Vijayalakshmi 2013; Rajeswari et al. 2013; Asaraja and Sahayaraj

Antibacterial (Agboke and Attama Compound not reported Antimicrobial, antioxidant (Chandrasekar et al. 2015) compound not reported

Anti-oxidation effects, protects human skin against cytotoxic effect of UVB and dietary supplement (Kondo et al. 1990;Jialal and Grundy 1992)

Analgesic, anti-cataract, anticoronary, anti-diabetic, antioxidant, Hepatoprotective, Vasodilator, protein-kinase-c-inhibitor

anticancer, Lipoxygenase inhibitor, Anti-bronchitic, anti-coronary (Jothi et al. 2015; Rajalakshmi and Mohan 2016)

\begin{tabular}{|c|c|c|c|}
\hline $\begin{array}{l}\text { 6h-Purin-6-one,1,7-dihydro- } \\
\text { 2(methylamino) }\end{array}$ & imidazole derivatives & $\mathrm{C}_{7} \mathrm{H}_{8} \mathrm{~N}_{4 \mathrm{O}}$ & 164 \\
\hline 1H-Purin-2-amine-6-methoxy & & $\mathrm{C}_{6} \mathrm{H}_{7} \mathrm{~N}_{5 \mathrm{O}}$ & 165 \\
\hline 26-nor-5-cholesten-3,beta,-ol-25-one & & $\mathrm{C}_{26} \mathrm{H}_{42} \mathrm{O}_{2}$ & 386 \\
\hline
\end{tabular}

Acts as anti-viral (active against HSV-1 and HSV-2) (Kumar et al. 2017)

No activity reported

Anti-tumor, anti-inflammatory, antioxidant and anti-bacterial (Yuvaraj and Arul 2014)

$\mathrm{C}_{25} \mathrm{H}_{36} \mathrm{O}_{5} \quad 416$
21-Acetoxypregnenolone

Anti-microbial, antioxidant, targets antisense strands (targets single stranded RNA complimentary to protein coding mRNA which hybridizes and block translation of protein) mainly use in gene knockdown

Antiproliferative activity against melanoma cells (Chidambaram et al. 1996; Kim et al. 2009; Chen et al. 2014)

Stem Hexadecanoic acid, methyl ester

$\mathrm{C}_{17} \mathrm{H}_{34} \mathrm{O}_{2} \quad 270$
Antioxidant, hypocholesterolenic, flavor, hemolytic 5-alpha reductase inhibitor nematicide, antiandrogenic (Easwaran and Ramani 2014)

N-hexadecanoic acid

Palmitic acid

$\mathrm{C}_{16} \mathrm{H}_{32} \mathrm{O}_{2}$

256

Anti-inflammatory, Antioxidant, hypocholesterolemic nematicide, pesticide, anti-androgenic flavor, hemolytic, 5-alpha reductase inhibitor (Kumar et al. 2010; Aparna et al. 2012)

\begin{tabular}{lllcclll}
\hline Isopropyl palmitate & & $\mathrm{C}_{19} \mathrm{H}_{38} \mathrm{O}_{2}$ & 298 & \multicolumn{2}{c}{$\begin{array}{l}\text { Anti-proliferative activity (Saxena } \\
\text { et al. 2007) }\end{array}$} \\
\hline 8,11,14 Eicosatrienoic acid, methyl & Methyl & dihomo- $\gamma-$ & $\mathrm{C}_{21} \mathrm{H}_{36} \mathrm{O}_{2}$ & 320 & Tumoricidal (Das and Madhavi
\end{tabular}




\begin{tabular}{|c|c|c|c|}
\hline 10-undecynoic acid, methyl ester & & $\mathrm{C}_{12} \mathrm{H}_{20} \mathrm{O}_{2}$ & 196 \\
\hline Octadecanoic acid, methyl ester & Methyl stearate & $\mathrm{C}_{19} \mathrm{H}_{38} \mathrm{O}_{2}$ & 298 \\
\hline $\begin{array}{l}\text { 9,12-octadecadienoyl } \\
(\mathrm{Z}, \mathrm{Z}) \text { - }\end{array}$ & Linoleoyl chloride & $\mathrm{C}_{18} \mathrm{H}_{31} \mathrm{ClO}$ & 298 \\
\hline
\end{tabular}
-oxidant (Palakkal et al. 2017) Antifungal and antioxidant (Pinto et al. 2017)

Anticancer, Anticoronary,
Antieczemic, Antihistamic (Kumar et al. 2015)

Hypocholesterolemic, surfactant
and softening agent, perfumery, flavor and in cosmetic

Antibacterial activity (Da Silva et al. 2003; Rajashyamala and Elango 2015)

\begin{tabular}{|c|c|c|c|c|}
\hline $\begin{array}{l}\text { Hexadecanoic } \quad \text { acid, } \\
\text { (hydroxymethyl)-1,2-ethanediyl } \\
\text { ester }\end{array}$ & $\begin{array}{l}\text { Glyceryl } \\
\text { dipalmitate }\end{array}$ & $\mathrm{C}_{35} \mathrm{H}_{68} \mathrm{O}_{5}$ & 568 & $\begin{array}{l}\text { Antimicrobial, Antioxidant (Kumar } \\
\text { et al. 2013) }\end{array}$ \\
\hline 2-piperidinone,N-(4-Bromo-N-butyl)- & Alkaloid & $\mathrm{C}_{9} \mathrm{H}_{34} \mathrm{O}_{7} \mathrm{~S}$ & 370 & $\begin{array}{l}\text { Anti-inflammatory, anti-microbial, } \\
\text { anti-cancer (Jothi et al. 2015) }\end{array}$ \\
\hline oleic acid & Carboxylic acid & $\mathrm{C}_{18} \mathrm{H}_{34} \mathrm{O}_{2}$ & 282.468 & 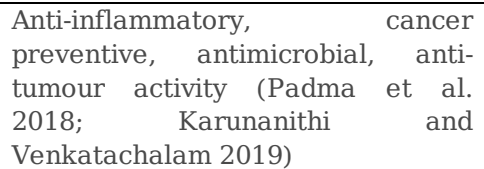 \\
\hline $\begin{array}{lcc}\text { Hexadecanoic } & \text { acid, } & 3- \\
\text { [(trimethylsilyl) oxy]propyl ester } & \end{array}$ & $\begin{array}{l}\text { 3- } \\
\text { Trimethylsilyloxypropyl } \\
\text { hexadecanoate } \\
\end{array}$ & $\mathrm{C}_{22} \mathrm{H}_{46} \mathrm{O}_{3} \mathrm{Si}$ & 386 & $\begin{array}{l}\text { Antimicrobial, } \\
\text { (Chandrasekar et al. 2015) }\end{array}$ \\
\hline $\begin{array}{lll}\text { 4-cyanobenzoic } & \text { acid, } & \text { Tridec-2- } \\
\text { YNYL,ester } & & \\
\end{array}$ & & $\mathrm{C}_{21} \mathrm{H}_{27} \mathrm{NO}_{2}$ & 325 & No activity reported \\
\hline Bisnor-7-desoxycholic acid & & $\mathrm{C}_{22} \mathrm{H}_{36} \mathrm{O}_{4}$ & 364 & $\begin{array}{l}\text { Antimicrobial, } \\
\text { Anticancer (Wei et al. 2011) }\end{array}$ \\
\hline 26-hydroxycholesterol & LDL & $\mathrm{C}_{27} \mathrm{H}_{46} \mathrm{O}_{2}$ & 402 & $\begin{array}{l}\text { Inhibition of cholesterol synthesis } \\
\text { (Javitt 1990) }\end{array}$ \\
\hline pseduosarsasapogenin-5,20-dien & & $\mathrm{C}_{27} \mathrm{H}_{42} \mathrm{O}_{3}$ & 414 & $\begin{array}{l}\text { Treatment of Amyotrophic lateral } \\
\text { sclerosis (Sulthanabegam et al. } \\
\text { 2019) }\end{array}$ \\
\hline $\begin{array}{l}\text { 1-napthalenepropanol, Alpha-ethyl } \\
\text { decahydro-5(hydroxymethyl) }\end{array}$ & & $\mathrm{C}_{20} \mathrm{H}_{36} \mathrm{O}_{2}$ & 308 & No activity reported \\
\hline $\begin{array}{ll}\text { Cholest-5-en-3-ol } & \text { (3.beta)., } \\
\text { carbonochloridate } & \\
\end{array}$ & & $\mathrm{C}_{28} \mathrm{H}_{45} \mathrm{CIO}_{2}$ & 448 & $\begin{array}{l}\text { Antibacterial (Agboke and Attama } \\
\text { 2016) }\end{array}$ \\
\hline 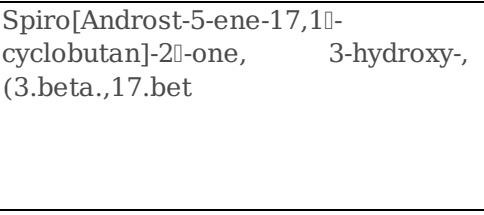 & & $\mathrm{C}_{22} \mathrm{H}_{32} \mathrm{O}_{2}$ & 328 & $\begin{array}{lr}\text { Anti-inflammatory } & \text { and anti- } \\
\text { microbial } & \\
\text { Antiarthritic, } & \text { anticancer, } \\
\text { antiasthma, Hepatoprotective } \\
\text { (Sathiyabalan et al. 2014; Okereke } \\
\text { et al. 2017) }\end{array}$ \\
\hline Serverogenin acetate & & $\mathrm{C}_{29} \mathrm{H}_{36} \mathrm{O}_{10}$ & 544 & $\begin{array}{l}\text { Anti-insect, anti-microbial, anti- } \\
\text { oxidant, anti-cancer, and anti- } \\
\text { ulcerogenic activity (Karunanithi } \\
\text { and Venkatachalam 2019) }\end{array}$ \\
\hline pseduosarsasapogenin-5,20-dien & & $\mathrm{C}_{27} \mathrm{H}_{42} \mathrm{O}_{3}$ & 414 & $\begin{array}{l}\text { Treatment of Amyotrophic lateral } \\
\text { sclerosis (Sulthanabegam et al. } \\
\text { 2019) }\end{array}$ \\
\hline Trans-Z-Alpha-Bisabolene epoxide & & $\mathrm{C}_{15} \mathrm{H}_{24} \mathrm{O}$ & 220 & $\begin{array}{l}\text { Anti-bacterial activity } \\
\text { Anti-inflammatory effects (Hameed } \\
\text { et al. 2016) }\end{array}$ \\
\hline Limonene-6-ol,Pivalate & & $\mathrm{C}_{15} \mathrm{H}_{24} \mathrm{O}_{2}$ & 236 & $\begin{array}{l}\text { Anti-inflammatory and antioxidant } \\
\text { anti-stress activity (Hadi et al. } \\
\text { 2015; Hussein 2016) }\end{array}$ \\
\hline $\begin{array}{l}\text { Arachidonic amide,N-(5-Hydroxy-N- } \\
\text { pentyl) }\end{array}$ & & $\mathrm{C}_{25} \mathrm{H}_{43} \mathrm{NO}_{2}$ & 389 & $\begin{array}{l}\text { COX enzyme expression for } \\
\text { catalysis of prostalglandins (plays } \\
\text { a significant role in health and } \\
\text { disease in the gastrointestinal tract } \\
\text { (GI), in renal, skeletal and ocular } \\
\text { system (Barry et al. 1997; Autore } \\
\text { et al. 2010) }\end{array}$ \\
\hline 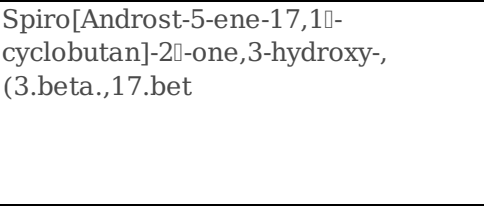 & & $\mathrm{C}_{22} \mathrm{H}_{32} \mathrm{O}_{2}$ & 328 & $\begin{array}{l}\text { Anti-inflammatory and anti- } \\
\text { microbial } \\
\text { Antiarthritic, } \\
\text { antiasthma, Hepatoprotective } \\
\text { (Sathiyabalan et al. 2014; Okereke } \\
\text { et al. 2017) }\end{array}$ \\
\hline 7.dehydrocholesterol isocaproate & & & & compound not reported \\
\hline 2,4-dinitrophenyl & & & & compound not reported \\
\hline
\end{tabular}




\begin{tabular}{lllllll}
\hline Beta-Carotene & Vitamin A precursor & $\mathrm{C}_{40} \mathrm{H}_{56}$ & 536 & used in leukaemia therapies,
\end{tabular}

cardiovascular disease protective

(Dreosti 1996; Zaini et al. 2012)

Coprostan-3. Beta, 16. Beta-Diol

compound not reported

Pentadecanoic acid, 14 methyl

Palmitic acid methyl $\mathrm{C}_{19} \mathrm{H}_{34} \mathrm{O}_{2}$

270

Antioxidant, antifungal ester-, methyl ester ester

Arumugam 2014; Elaiyaraja and Chandramohan 2016)

\begin{tabular}{lllll}
\hline N-hexadecanoic acid & Palmitic acid & $\mathrm{C}_{16} \mathrm{H}_{32} \mathrm{O}_{2}$ & 256 & Anti-inflammatory, Antioxidant,
\end{tabular} hypocholestero

lemic nematicide, pesticide, antiandrogenic flavor, hemolytic, 5alpha reductase inhibitor (Kumar et al. 2010; Aparna et al. 2012)

\begin{tabular}{llcc}
\hline Undecanoic acid & carboxylic acid & $\mathrm{C}_{11} \mathrm{H}_{22} \mathrm{O}_{2}$ & 186.295 \\
\hline $\begin{array}{l}\text { 8,11,14- Eicosatrienoic acid, methyl } \\
\text { ester }\end{array}$ & $\begin{array}{l}\text { Methyl dihomo- } \gamma- \\
\text { linoleic acid }\end{array}$ & $\mathrm{C}_{21} \mathrm{H}_{36} \mathrm{O}_{2}$ & 320 \\
\hline (Z)6,(Z)9-Pentadecadien-1-ol & & $\mathrm{C}_{15} \mathrm{H}_{28} \mathrm{O}$ & 224 \\
\hline P-menth-8(10)-en-0-ol, cis & & $\mathrm{C}_{10} \mathrm{H}_{18} \mathrm{O}$ & 154
\end{tabular}

Anti-mycotic activity (Padma et al. 2018)

Tum 2011)

Antifungal (Umaiyambigai et al. 2017)

Sedative effect, depressant effect in the CNS, such as anticonvulsants and anxiolytics, increase the time of sleep, larvicidal and repellant activity against dengue fever (De Sousa et al. 2007; Balasubramani et al. 2018)

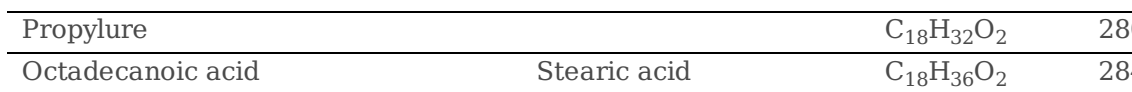

Sex pheromone (Jacobson 1969)

Hypocholesterolemic, surfactant and softening agent, perfumery, flavor and in cosmetic

Antibacterial activity (Da Silva et al. 2003; Rajashyamala and Elango 2015)

\begin{tabular}{lll}
\hline Alpha-Ketostearic acid, ethyl ester & $\mathrm{C}_{20} \mathrm{H}_{38} \mathrm{O}_{3}$ & 326 \\
\hline $\mathrm{Z}, \mathrm{Z}, \mathrm{Z}-1,4,6,9-$ Nonadecatetraene & $\mathrm{C}_{19} \mathrm{H}_{32}$ & 260
\end{tabular}

No activity reported

Antioxidant (Naidu et al. 2012; Suffo et al. 2016)

1-Dodecen-3-yne

Anti- skin pathogen, Anti-oxidant (Kim et al. 2011)

\begin{tabular}{|c|c|c|c|c|}
\hline $\begin{array}{lcc}\text { Hexadecanoic } & \text { acid, } & 1- \\
\text { (hydroxymethyl)-1,2-ethanediyl } & \\
\text { ester } & & \\
\end{array}$ & $\begin{array}{l}\text { Glyceryl } \\
\text { dipalmitate }\end{array}$ & $\mathrm{C}_{35} \mathrm{H}_{68} \mathrm{O}_{5}$ & 568 & $\begin{array}{l}\text { Antimicrobial, Antioxidant (Kumar } \\
\text { et al. 2013) }\end{array}$ \\
\hline $\begin{array}{l}\text { 2-piperidinone,N-(4-Bromo-N- } \\
\text { Butyl)- }\end{array}$ & Alkaloid & $\mathrm{C}_{9} \mathrm{H}_{16} \mathrm{BrNO}$ & 233 & $\begin{array}{l}\text { Anti-inflammatory } \\
\text { Anti-microbial } \\
\text { Anti-cancer (Jothi et al. 2015) }\end{array}$ \\
\hline $\begin{array}{l}\text { Oxiraneundecanoic acid, 3-pentyl, } \\
\text { methyl ester, cis }\end{array}$ & & $\mathrm{C}_{19} \mathrm{H}_{36} \mathrm{O}_{3}$ & 312 & $\begin{array}{l}\text { Larvicidal activity } \\
\text { Antioxidant activity (Elumalai et al. } \\
\text { 2015; Al-Marzoqi et al. 2016) }\end{array}$ \\
\hline $\begin{array}{l}\text { 9-octadecanoic acid (Z)-, 2-Hydroxy- } \\
\text { 1-(hydroxymethyl) ethyl ester }\end{array}$ & $\begin{array}{l}\text { Fatty acid ethyl ester, } \\
\text { Oleic acid compound }\end{array}$ & $\mathrm{C}_{21} \mathrm{H}_{40} \mathrm{O}_{4}$ & 356 & $\begin{array}{l}\text { No activity reported (Vijisaral and } \\
\text { Arumugam 2014; Rajalakshmi and } \\
\text { Mohan 2016) }\end{array}$ \\
\hline $\begin{array}{lr}\text { Spiro[Androst-5-ene-17, } & \text { 1'- } \\
\text { cyclobutan]-2'-one, } & \text { 3-hydroxy-, } \\
\text { (3.beta.,17.bet } & \end{array}$ & & $\mathrm{C}_{22} \mathrm{H}_{32} \mathrm{O}_{2}$ & 328 & $\begin{array}{lr}\text { Anti-inflammatory } & \text { and anti- } \\
\text { microbial } & \\
\text { Antiarthritic, } & \text { anticancer, } \\
\text { antiasthma, Hepatoprotective } \\
\text { (Sathiyabalan et al. 2014; Okereke } \\
\text { et al. 2017) }\end{array}$ \\
\hline Serverogenin acetate & & $\mathrm{C}_{29} \mathrm{H}_{36} \mathrm{O}_{10}$ & 544 & $\begin{array}{l}\text { Anti-insect, anti-microbial, anti- } \\
\text { oxidant, anti-cancer, and anti- } \\
\text { ulcerogenic activity (Karunanithi } \\
\text { and Venkatachalam 2019) }\end{array}$ \\
\hline pseduosarsasapogenin-5,20-dien & & $\mathrm{C}_{27} \mathrm{H}_{42} \mathrm{O}_{3}$ & 414 & $\begin{array}{l}\text { Treatment of Amyotrophic lateral } \\
\text { sclerosis (Sulthanabegam et al. } \\
\text { 2019) }\end{array}$ \\
\hline Trans-Z-Alpha- bisabolene epoxide & & $\mathrm{C}_{15} \mathrm{H}_{24} \mathrm{O}$ & 220 & $\begin{array}{l}\text { Anti-bacterial activity } \\
\text { Anti-inflammatory effects (Hameed } \\
\text { et al. 2016) }\end{array}$ \\
\hline $\begin{array}{l}\text { Arachidonic amide, N-(5-hydroxy-N- } \\
\text { pentyl) }\end{array}$ & & $\mathrm{C}_{25} \mathrm{H}_{43} \mathrm{NO}_{2}$ & 389 & $\begin{array}{l}\text { COX enzyme expression for } \\
\text { catalysis of prostalglandins (plays } \\
\text { a significant role in health and }\end{array}$ \\
\hline
\end{tabular}


disease in the gastrointestinal tract (GI), in renal, skeletal and ocular system (Barry et al. 1997; Autore et al. 2010)

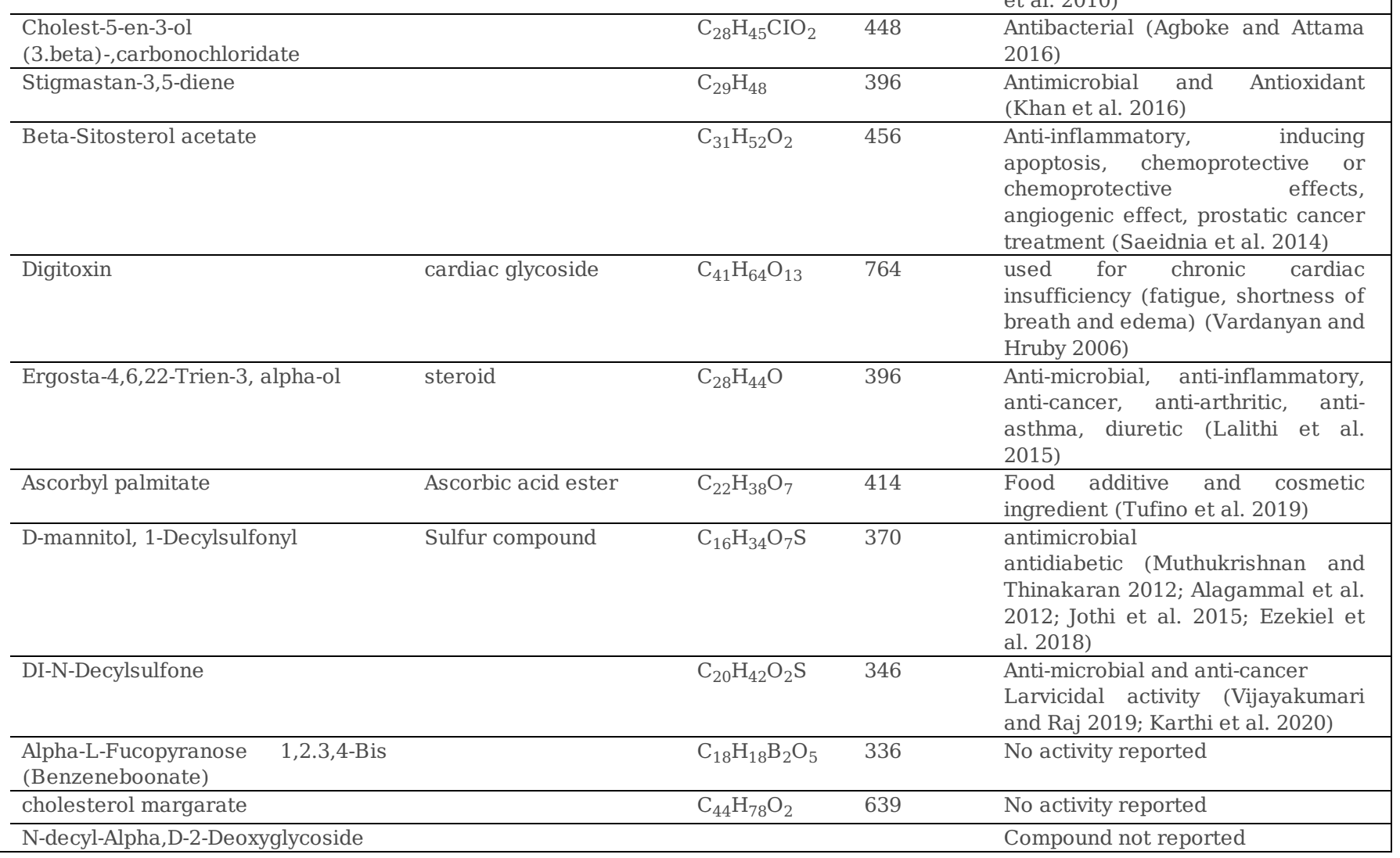

Table 2 GC-MS analysis of ethanol extracts of Pleione maculata 


\begin{tabular}{|c|c|c|c|c|c|}
\hline $\begin{array}{l}\text { Parts of } \\
P . \\
\text { maculata }\end{array}$ & Peak name & $\begin{array}{l}\text { Molecular } \\
\text { name }\end{array}$ & $\begin{array}{l}\text { Molecular } \\
\text { formula }\end{array}$ & $\begin{array}{l}\text { Molecular } \\
\text { weight }\end{array}$ & Activity \\
\hline \multirow[t]{9}{*}{ Leaves } & $\begin{array}{l}\text { Phenol, } \\
\text { (ethoxymethyl) }\end{array}$ & $\begin{array}{l}\text { 4- } \\
\text { (Ethoxymethyl) } \\
\text { Phenol }\end{array}$ & $\mathrm{C}_{9} \mathrm{H}_{12} \mathrm{O}_{2}$ & 152 & No activity reported \\
\hline & $\begin{array}{l}\text { 2.pyridinecarboxylic } \\
\text { acid, 6-methoxy }\end{array}$ & & $\mathrm{C}_{8} \mathrm{H}_{9} \mathrm{NO}_{3}$ & 153 & No activity reported \\
\hline & $\begin{array}{l}\text { 1-methyl sulfanyl -9- } \\
\text { 10-Dioxo-9,10- } \\
\text { dihydro-anthracene- } \\
\text { 2-carbxylic acid }\end{array}$ & & $\mathrm{C}_{23} \mathrm{H}_{17} \mathrm{NO}_{3} \mathrm{~S}$ & 387 & No activity reported \\
\hline & $\begin{array}{l}\text { N-hexadecanoic } \\
\text { acid }\end{array}$ & Palmitic acid & $\mathrm{C}_{16} \mathrm{H}_{32} \mathrm{O}_{2}$ & 256 & $\begin{array}{l}\text { Anti-inflammatory, Antioxidant, hypocholesterolemic } \\
\text { nematicide, pesticide, anti-androgenic flavor, hemolytic, 5- } \\
\text { alpha reductase inhibitor (Kumar et al. 2010; Aparna et al. } \\
\text { 2012) }\end{array}$ \\
\hline & $\begin{array}{l}\text { N-hexadecanoic } \\
\text { acid }\end{array}$ & Palmitic acid & $\mathrm{C}_{16} \mathrm{H}_{32} \mathrm{O}_{2}$ & 256 & $\begin{array}{l}\text { Anti-inflammatory, Antioxidant, hypocholesterolemic } \\
\text { nematicide, pesticide, anti-androgenic flavor, hemolytic, 5- } \\
\text { alpha reductase inhibitor (Kumar et al. 2010; Aparna et al. } \\
\text { 2012) }\end{array}$ \\
\hline & Ethyl tridecanoate & & $\mathrm{C}_{15} \mathrm{H}_{30} \mathrm{O}_{2}$ & 242 & Antioxidant (Qurzeddine et al. 2017) \\
\hline & $\begin{array}{l}\text { Octadecanoic acid, } \\
\text { 2-(2-hydroxyethoxy) } \\
\text { ethyl ester }\end{array}$ & $\begin{array}{l}\text { Diethylene } \\
\text { glycol stearate }\end{array}$ & $\mathrm{C}_{22} \mathrm{H}_{44} \mathrm{O}_{4}$ & 372 & $\begin{array}{l}\text { Used in cosmetic, textile, serve as plasticizer, lubricant, } \\
\text { binding and thickening agent (Oduje et al. 2015) }\end{array}$ \\
\hline & N-butyl myristate & & $\mathrm{C}_{18} \mathrm{H}_{36} \mathrm{O}_{2}$ & 284 & $\begin{array}{l}\text { used as plasticizers } \\
\text { anti-microbial activity (Sujatha et al. 2014) }\end{array}$ \\
\hline & $\begin{array}{l}\text { Guanidine acetic } \\
\text { acid }\end{array}$ & Glycocyamine & $\mathrm{C}_{3} \mathrm{H}_{7} \mathrm{~N}_{3} \mathrm{O}_{2}$ & 117 & $\begin{array}{l}\text { Antibacterial activity } \\
\text { Biosynthesis of creatine as a suitable food and feed } \\
\text { supplement } \\
\begin{array}{l}\text { Beneficial effect on the stamina (US 8, 501, } 810 \text { B2) } \\
\text { (Gastner and Krimmer 2013) }\end{array}\end{array}$ \\
\hline \multirow[t]{11}{*}{ Stem } & $\begin{array}{l}\text { Phenol,4- } \\
\text { (ethoxymethyl) }\end{array}$ & $\begin{array}{l}\text { - } \\
\text { (Ethoxymethyl) } \\
\text { Phenol }\end{array}$ & $\mathrm{C}_{9} \mathrm{H}_{12} \mathrm{O}_{2}$ & 152 & No activity reported \\
\hline & $\begin{array}{l}1,2- \\
\text { benzenedicarboxylic } \\
\text { acid, butyl octyl } \\
\text { ester }\end{array}$ & $\begin{array}{ll}\text { Phthalic } & \text { acid, } \\
\text { butyl } & \text { octyl } \\
\text { ester, } & \\
\text { Plasticizer } & \\
\text { BOP } & \\
\end{array}$ & $\mathrm{C}_{20} \mathrm{H}_{30} \mathrm{O}_{4}$ & 334 & $\begin{array}{l}\text { Antimicrobial, Antifouling (Lakshmi and Rajalakshmi } \\
\text { 2011; Khalil et al. 2014) }\end{array}$ \\
\hline & $\begin{array}{l}\text { N-hexadecanoic } \\
\text { acid }\end{array}$ & Palmitic acid & $\mathrm{C}_{16} \mathrm{H}_{32} \mathrm{O}_{2}$ & 256 & $\begin{array}{l}\text { Anti-inflammatory, Antioxidant, hypocholesterolemic } \\
\text { nematicide, pesticide, anti-androgenic flavor, hemolytic, 5- } \\
\text { alpha reductase inhibitor (Kumar et al. 2010; Aparna et al. } \\
\text { 2012) }\end{array}$ \\
\hline & $\begin{array}{l}\text { Hexadecanoic acid, } \\
\text { ethyl ester }\end{array}$ & $\begin{array}{l}\text { Palmitic acid } \\
\text { ester }\end{array}$ & $\mathrm{C}_{18} \mathrm{H}_{36} \mathrm{O}_{2}$ & 284 &  \\
\hline & $\begin{array}{l}9,12- \\
\text { octadecadienoic } \\
\text { acid }(Z, Z)-\end{array}$ & $\begin{array}{l}\text { Conjugated } \\
\text { Linoleic acid }\end{array}$ & $\mathrm{C}_{18} \mathrm{H}_{32} \mathrm{O}_{2}$ & 280 & $\begin{array}{l}\text { Anti-Inflammatory, hypocholesterolic, cancer preventive, } \\
\text { Hepatoprotective, nematicide, antihistaminic, antieczemic, } \\
\text { antiacne, 5- } \alpha \text { reductase inhibitor, anti-coronary, } \\
\text { antimicrobial (Adeoye-Isijola et al. 2018) }\end{array}$ \\
\hline & $\begin{array}{l}\text { Linoleic acid ethyl } \\
\text { ester }\end{array}$ & & $\mathrm{C}_{20} \mathrm{H}_{34} \mathrm{O}_{2}$ & 308 & $\begin{array}{l}\text { Hypocholesterolemic, nematicide, anti-arthritic, } \\
\text { hepatoproctective, anti-androgenic, hypycholesterolemic, 5- } \\
\text { alpha reductase inhibitor, anti-histaminic, anti-coronary, } \\
\text { insectifuge, anti-eczemic, anti-acne (Chidambarampillai } \\
\text { and Mohan 2013; Tyagi and Agarwal 2016) }\end{array}$ \\
\hline & Isopropyl linoleate & & $\mathrm{C}_{21} \mathrm{H}_{38} \mathrm{O}_{2}$ & 322 & $\begin{array}{l}\text { Antioxidant, antidiabetic, anti-inflammatory } \\
\text { Formulation of skin and hair care products, facial makeup } \\
\text { (Rajendra et al. 2017; Rautela et al. 2018) }\end{array}$ \\
\hline & $\begin{array}{l}\text { Dichloroacetic acid, } \\
\text { dodec-9-YNYL }\end{array}$ & & $\mathrm{C}_{14} \mathrm{H}_{23} \mathrm{ClO}_{2}$ & 292 & $\begin{array}{l}\text { Acidifier, arachidonic acid inhibitor, increase aromatic } \\
\text { amino acid decarboxylase activity, inhibit production of uric } \\
\text { acid (Mohammad et al. 2019) }\end{array}$ \\
\hline & Oleic acid & & $\mathrm{C}_{18} \mathrm{H}_{34} \mathrm{O}_{2}$ & 282 & Antibacterial activity (Abubakar and Majinda 2016) \\
\hline & $\begin{array}{l}\text { Estra-1,3,5 (10)- } \\
\text { Trien-17-Beta-ol }\end{array}$ & & $\mathrm{C}_{18} \mathrm{H}_{24} \mathrm{O}$ & 256 & Anti-arrhythmic activity (Al-Gara'awi 2019) \\
\hline & $\begin{array}{l}\text { 9-Oxononanoic acid } \\
\text { (9-ONA) }\end{array}$ & & $\mathrm{C}_{9} \mathrm{H}_{16} \mathrm{O}_{3}$ & 172 & $\begin{array}{l}\text { Lipid peroxidation (treats disorder such as inflammation, } \\
\text { atherosclerosis and other degenerative diseases) induces } \\
\text { phospholipase A2 activity and thromboxane A2 production } \\
\text { in human blood (Ren et al. 2013) }\end{array}$ \\
\hline \multirow[t]{2}{*}{ Roots } & $\begin{array}{l}\text { Phthalic acid, butyl } \\
\text { hexyl ester }\end{array}$ & $\begin{array}{l}\text { Butyl hexyl } \\
\text { phthalate }\end{array}$ & $\mathrm{C}_{18} \mathrm{H}_{26} \mathrm{O}_{4}$ & 306 & Antimicrobial (Ingole 2016) \\
\hline & $\begin{array}{l}\text { 1,2- } \\
\text { benzenedicarboxylic }\end{array}$ & $\begin{array}{ll}\text { Phthalic } & \text { acid, } \\
\text { butyl } & \text { octyl } \\
\text { ester, } & \end{array}$ & $\mathrm{C}_{20} \mathrm{H}_{30} \mathrm{O}_{4}$ & 334 & $\begin{array}{l}\text { Antimicrobial, Antifouling (Lakshmi and Rajalakshmi } \\
\text { 2011; Khalil et al. 2014) }\end{array}$ \\
\hline
\end{tabular}


acid, butyl octyl Plasticizer

ester BOP

Table 3 GC-MS analysis of methanol extracts of Pleione maculata 


\begin{tabular}{|c|c|c|c|c|c|}
\hline $\begin{array}{l}\text { Parts of } \\
P \text {. } \\
\text { maculata }\end{array}$ & Peak name & $\begin{array}{l}\text { Molecular } \\
\text { name }\end{array}$ & $\begin{array}{l}\text { Molecular } \\
\text { formula }\end{array}$ & $\begin{array}{l}\text { Molecular } \\
\text { weight }\end{array}$ & Activity \\
\hline \multirow[t]{10}{*}{ leaves } & \multicolumn{2}{|l|}{ Phenol, 4-(methoxymethyl)- } & $\mathrm{C}_{8} \mathrm{H}_{10} \mathrm{O}_{2}$ & 138 & Anti-diabetic Balamurugan et al. 2017) \\
\hline & $\begin{array}{l}\text { Pentadecanoic acid, 14- } \\
\text { methyl-, methyl ester }\end{array}$ & $\begin{array}{l}\text { Palmitic acid } \\
\text { methyl ester }\end{array}$ & $\mathrm{C}_{19} \mathrm{H}_{34} \mathrm{O}_{2}$ & 270 & Antioxidant (Vijisaral and Arumugam 2014) \\
\hline & N-hexadecanoic acid & Palmitic acid & $\mathrm{C}_{16} \mathrm{H}_{32} \mathrm{O}_{2}$ & 256 & $\begin{array}{l}\text { Anti-inflammatory, } \\
\text { hypocholesterolemic nematicide, pesticide, } \\
\text { anti-androgenic flavor, hemolytic, 5-alpha } \\
\text { reductase inhibitor (Kumar et al. 2010; Aparna } \\
\text { et al. 2012) }\end{array}$ \\
\hline & 9-octadecyne & $\begin{array}{l}\text { Alkene } \\
\text { compound }\end{array}$ & $\mathrm{C}_{18} \mathrm{H}_{34}$ & 250 & $\begin{array}{l}\text { Antioxidant, Antimicrobial } \quad \text { (Upgade and } \\
\text { Bhaskar 2013) }\end{array}$ \\
\hline & \multicolumn{2}{|l|}{ Isopropyl linoleate } & $\mathrm{C}_{21} \mathrm{H}_{38} \mathrm{O}_{2}$ & 322 & $\begin{array}{l}\text { Antioxidant, antidiabetic, anti-inflammatory } \\
\text { Formulation of skin and hair care products, } \\
\text { facial makeup (Rajendra et al. 2017; Rautela } \\
\text { et al. 2018) }\end{array}$ \\
\hline & $\begin{array}{l}\text { 6-octadecenoic acid, methyl } \\
\text { ester, }(\mathrm{Z}) \text { - }\end{array}$ & $\begin{array}{l}\text { Trans-13- } \\
\text { octadecanoic } \\
\text { acid, methyl } \\
\text { ester } 7\end{array}$ & $\mathrm{C}_{19} \mathrm{H}_{36} \mathrm{O}_{2}$ & 296 & 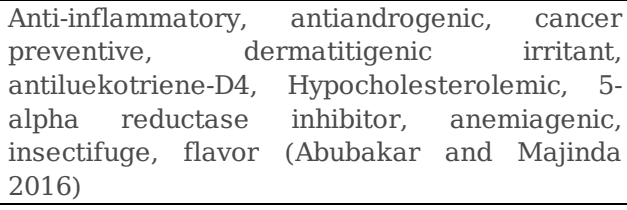 \\
\hline & \multicolumn{2}{|l|}{$\begin{array}{l}\text { Oxiraneundecanoic acid, 3- } \\
\text { pentyl, methyl ester, cis }\end{array}$} & $\mathrm{C}_{19} \mathrm{H}_{36} \mathrm{O}_{3}$ & 312 & $\begin{array}{l}\text { Larvicidal activity } \\
\text { Antioxidant activity (Elumalai et al. 2015;Al- } \\
\text { Marzoqi 2016) }\end{array}$ \\
\hline & $\begin{array}{l}\text { Octadecanoic acid, methyl } \\
\text { ester }\end{array}$ & Methyl stearate & $\mathrm{C}_{19} \mathrm{H}_{38} \mathrm{O}_{2}$ & 298 & Antifungal and antioxidant (Pinto et al. 2017) \\
\hline & N-hexadecanoic acid & Palmitic acid & $\mathrm{C}_{16} \mathrm{H}_{32} \mathrm{O}_{2}$ & 256 & $\begin{array}{l}\text { Anti-inflammatory, } \\
\text { hypocholesterolemic nematicide, pesticide, } \\
\text { anti-androgenic flavor, hemolytic, 5-alpha } \\
\text { reductase inhibitor (Kumar et al. 2010; Aparna } \\
\text { et al. 2012) }\end{array}$ \\
\hline & $\begin{array}{l}\text { Heptacosanoic acid, methyl } \\
\text { ester }\end{array}$ & $\begin{array}{l}\text { Methyl } \\
\text { heptacosanoate }\end{array}$ & $\mathrm{C}_{28} \mathrm{H}_{56} \mathrm{O}_{2}$ & 424 & No activity reported \\
\hline \multirow[t]{9}{*}{ Stem } & $\begin{array}{l}\text { Hexadecanoic acid, methyl } \\
\text { ester }\end{array}$ & & $\mathrm{C}_{17} \mathrm{H}_{34} \mathrm{O}_{2}$ & 270 & $\begin{array}{l}\text { Antibacterial and antifungal (Abubakar and } \\
\text { Majinda 2016) }\end{array}$ \\
\hline & N-hexadecanoic acid & Palmitic acid & $\mathrm{C}_{16} \mathrm{H}_{32} \mathrm{O}_{2}$ & 256 & $\begin{array}{l}\text { Anti-inflammatory, } \\
\text { hypocholesterolemic nematicide, pesticide, } \\
\text { anti-androgenic flavor, hemolytic, 5-alpha } \\
\text { reductase inhibitor (Kumar et al. 2010; Aparna } \\
\text { et al. 2012) }\end{array}$ \\
\hline & \multicolumn{2}{|l|}{$\begin{array}{l}(2 \mathrm{~s}, 3 \mathrm{~s})-(-)-3-\text { propyloxirane } \\
\text { methanol }\end{array}$} & $\mathrm{C}_{6} \mathrm{H}_{12} \mathrm{O}_{2}$ & 116 & Anti-oxidant (Yusufzai et al. 2019) \\
\hline & \multicolumn{2}{|l|}{$\begin{array}{l}\text { pyrimidine-2,4,6(1H,3H,5H)- } \\
\text { Trione-1-octadecyl) }\end{array}$} & & & $\begin{array}{l}\text { compound not reported } \\
\text { 2,4,6-trisubstituted pyrimidine were evaluated } \\
\text { as anti-malaria drug (Agrawal et al. 2005) S }\end{array}$ \\
\hline & \multirow{2}{*}{\multicolumn{2}{|c|}{$\begin{array}{l}\text { 2,3-anhydro-D-galactosan } \\
\text { 9,12-octadecadienoic acid, } \\
\text { methyl ester }\end{array}$}} & $\mathrm{C}_{6} \mathrm{H}_{8} \mathrm{O}_{4}$ & 144 & preservative (Paulpriya rt al. 2014) \\
\hline & & & $\mathrm{C}_{19} \mathrm{H}_{34} \mathrm{O}_{2}$ & 294 & $\begin{array}{l}\text { Anticancer, anti-inflammatory, antileukotriene, } \\
\text { flavor (Abubakar and Majinda 2016) }\end{array}$ \\
\hline &  & $\begin{array}{l}\text { Trans-13- } \\
\text { octadecanoic } \\
\text { acid, methyl } \\
\text { ester } 7\end{array}$ & $\mathrm{C}_{19} \mathrm{H}_{36} \mathrm{O}_{2}$ & 296 & 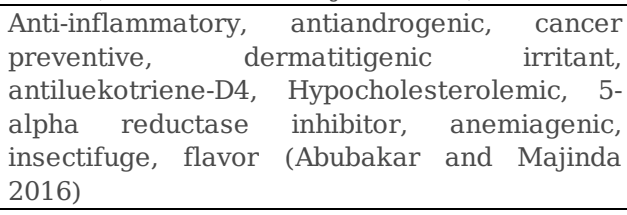 \\
\hline & $\begin{array}{l}\text { Octadecanoic acid, methyl } \\
\text { ester }\end{array}$ & Methyl stearate & $\mathrm{C}_{19} \mathrm{H}_{38} \mathrm{O}_{2}$ & 298 & Antifungal and antioxidant (Pinto et al. 2017) \\
\hline & $\begin{array}{l}\text { Triacontanoic acid, methyl } \\
\text { ester }\end{array}$ & $\begin{array}{l}\text { Methyl } \\
\text { triacontanate }\end{array}$ & $\mathrm{C}_{31} \mathrm{H}_{62} \mathrm{O}_{2}$ & 466 & Antimicrobial Kumar et al. 2015) \\
\hline \multirow[t]{5}{*}{ Roots } & $\begin{array}{l}\text { Hexadecanoic acid, methyl } \\
\text { ester }\end{array}$ & & $\mathrm{C}_{17} \mathrm{H}_{34} \mathrm{O}_{2}$ & 270 & $\begin{array}{l}\text { Antibacterial and antifungal activity (Abubakar } \\
\text { and Majinda 2016) }\end{array}$ \\
\hline & \multicolumn{2}{|l|}{ 9,12-octadecadienal } & $\mathrm{C}_{18} \mathrm{H}_{32} \mathrm{O}$ & 264 & $\begin{array}{l}\text { Antimicrobial and antioxidant (Gurnani et al. } \\
\text { 2015) }\end{array}$ \\
\hline & E,E-1,9,17-Docasatriene & $\begin{array}{l}\text { alkene } \\
\text { compound }\end{array}$ & $\mathrm{C}_{22} \mathrm{H}_{40}$ & 304 & $\begin{array}{l}\text { No activity reported (Subavathy and Thilaga } \\
\text { 2016; Kumaravel et al. 2016, 2019) }\end{array}$ \\
\hline & $\begin{array}{l}\text { 9-octadecenoic acid, methyl } \\
\text { ester }\end{array}$ & $\begin{array}{l}\text { Trans-13- } \\
\text { octadecanoic } \\
\text { acid, methyl } \\
\text { ester } 7\end{array}$ & $\mathrm{C}_{19} \mathrm{H}_{36} \mathrm{O}_{2}$ & 296 & $\begin{array}{l}\text { Anti-inflammatory, antiandrogenic, cancer } \\
\text { preventive, dermatitigenic irritant, } \\
\text { antiluekotriene-D4, Hypocholesterolemic, 5- } \\
\text { alpha reductase inhibitor, anemiagenic, } \\
\text { insectifuge, flavor (Abubakar and Majinda } \\
\text { 2016) }\end{array}$ \\
\hline & Nonanal & aldehyde & $\mathrm{C}_{9} \mathrm{H}_{18} \mathrm{O}$ & 142 & Anti-aging use in cosmetics \\
\hline
\end{tabular}


Fungicides (Plainfosse et al. 2017; Zhang et al. 2017)

Adjunctive treatment of partial seizures, use in neuropathic pain, neuralgia, use in alcohol withdrawal syndrome, restless leg syndromes, migraine and vasomotor symptoms of menopause (World Health Organization (WHO) 2018)

\begin{tabular}{|c|c|c|c|c|c|}
\hline $\begin{array}{l}\text { Octadecanoic } \\
\text { ester }\end{array}$ & acid, methyl & Methyl stearate & $\mathrm{C}_{19} \mathrm{H}_{38} \mathrm{O}_{2}$ & 298 & Antifungal and antioxidant (Pinto et al. 2017) \\
\hline $\begin{array}{l}\text { Tetracosanoic } \\
\text { ester }\end{array}$ & acid, methyl & $\begin{array}{l}\text { Methyl } \\
\text { lignocerate }\end{array}$ & $\mathrm{C}_{25} \mathrm{H}_{50} \mathrm{O}_{2}$ & 382 & $\begin{array}{l}\text { Antibacterial, Antimicrobial (Valiei et al. } \\
\text { 2011; Ukil et al. 2015) }\end{array}$ \\
\hline $\begin{array}{l}\text { Vor-Diazepam, } \\
\text { hydroxymethyl) } \\
\text { oxy }\end{array}$ & $\begin{array}{l}\text { an- } \\
\text { aminocarbonyl }\end{array}$ & & $\mathrm{C}_{18} \mathrm{H}_{16} \mathrm{CIN}_{3} \mathrm{O}_{4}$ & 373 & No activity reported \\
\hline
\end{tabular}

Table 4: Docking analysis depicting the binding residues and their binding energy 


\begin{tabular}{|c|c|c|c|c|c|c|c|}
\hline $\begin{array}{l}\text { Protein } \\
\text { Name }\end{array}$ & Drug-likeness ligands & $\begin{array}{l}\text { Polar contact } \\
\text { binding residues }\end{array}$ & $\begin{array}{l}\text { Other } \\
\text { intermolecular } \\
\text { contact binding } \\
\text { residues }\end{array}$ & $\begin{array}{l}\text { Global } \\
\text { energy } \\
(\mathrm{kcal} / \mathrm{mol})\end{array}$ & $\begin{array}{l}\text { Attractive } \\
\text { Vdw } \\
(\mathrm{kcal} / \mathrm{mol})\end{array}$ & $\begin{array}{l}\text { Repulsive } \\
\text { Vdw } \\
(\mathrm{kcal} / \mathrm{mol})\end{array}$ & $\begin{array}{l}\mathrm{ACE} \\
(\mathrm{kcal} / \mathrm{mol})\end{array}$ \\
\hline \multirow{19}{*}{$\begin{array}{l}\text { RNA } \\
\text { dependent } \\
\text { RNA-pol } \\
(6 \mathrm{M} 71)\end{array}$} & 2,4,6-Pyrimidinetrione & $\begin{array}{l}\text { Cys } 780, \operatorname{Arg} 467, \\
\text { Leu } 470, \operatorname{Arg} 305\end{array}$ & $\begin{array}{l}\text { all side bonded by } \\
\text { polar contacts }\end{array}$ & -23.59 & -10.00 & 0.72 & -5.79 \\
\hline & 21-Acetoxypregenelone & $\begin{array}{l}\text { Ala 706, Leu 707, } \\
\text { Asn 705 }\end{array}$ & $\begin{array}{l}\text { Gly 774, Asp 135, } \\
\text { Ala 130, Ser } 709\end{array}$ & -34.15 & -20.12 & 10.12 & -8.38 \\
\hline & P- menth-8(10)-en-9-ol & Thr 141, Leu 142 & Ala 130, Asp 126 & -31.56 & -12.13 & 0.87 & -7.18 \\
\hline & $\begin{array}{lr}\text { Nor-diazepam, } & 3\{\mathrm{n}- \\
\text { hydroxymethyl\}aminocarbonyloxy }\end{array}$ & $\begin{array}{l}\text { Thr 556, Arg 555, } \\
\text { Arg 624 }\end{array}$ & $\begin{array}{l}\text { all side bonded by } \\
\text { polar contact }\end{array}$ & -35.35 & -23.08 & 4.90 & -3.16 \\
\hline & Digitoxin & $\begin{array}{l}\text { Lys 267, Ser 255, } \\
\text { Thr } 252\end{array}$ & $\begin{array}{l}\text { Ser 255, Tyr 265, } \\
\text { Thr } 319\end{array}$ & -79.90 & -36.74 & 12.20 & -22.96 \\
\hline & DI-N-Decylsulfone & $\begin{array}{l}\text { Tyr 546, Val 410, } \\
\text { Lys } 141\end{array}$ & $\begin{array}{l}\text { Lys 411, Asn 414, } \\
\text { Gln 408 }\end{array}$ & -44.31 & -19.74 & 2.12 & -11.57 \\
\hline & 14-dodecanoic acid & Lys 411 , Val 410 & $\begin{array}{l}\text { Tyr 546, Ser 15, } \\
\text { Asn } 414\end{array}$ & -29.99 & -14.73 & 2.24 & -6.96 \\
\hline & Estra-1,3,5(10)-trien-17-beta-ol & Gln $18, G \ln 19$ & Ser 15, Asn 414 & -36.68 & -20.43 & 4.20 & -6.57 \\
\hline & $\begin{array}{l}\text { Arachidonic amide,N-\{5-hydroxy- } \\
\text { N-Pentyl }\end{array}$ & Tyr 268 & Lys 267 & -46.08 & -21.29 & 4.04 & -12.04 \\
\hline & $\begin{array}{l}\text { 1-methylsulfanyl-9-10-Dioxo-9,10- } \\
\text { dihydro-Anthracene-2-carboxylic } \\
\text { acid }\end{array}$ & Asp 218, Thr 206 & $\begin{array}{l}\text { Tyr 217, Ile 37, } \\
\text { Tyr } 38\end{array}$ & -37.97 & -20.97 & 3.26 & -6.72 \\
\hline & Cholesterol margarate & Lys 391 & $\begin{array}{l}\text { Thr 393, Lys 395, } \\
\text { Asn } 136\end{array}$ & -70.69 & -31.28 & 9.37 & -21.60 \\
\hline & Docosanoic acid & no polar contact & $\begin{array}{l}\text { Ser 15, Asn 414, } \\
\text { Tyr 546, Lys } 411\end{array}$ & -47.59 & -23.22 & 8.71 & -13.13 \\
\hline & 26-hydroxycholesterol & Asn 781, Asp 126 & $\begin{array}{l}\text { Ser 784, Lys } 47 \text {, } \\
\text { Thr 141, Lys } 780\end{array}$ & -42.36 & -21.98 & 1.38 & -7.11 \\
\hline & Andrographolide & $\begin{array}{l}\text { Leu 142, Asp 140, } \\
\text { Tyr 129, Asn 781, } \\
\text { Ser 709, Leu } 708\end{array}$ & $\begin{array}{l}\text { Cys 139, Asp 140, } \\
\text { Thr 141, Lys } 47\end{array}$ & -37.42 & -19.40 & 4.39 & -8.43 \\
\hline & $\begin{array}{l}\text { 6H-purin-6-one,1,7-dihydro-2- } \\
\text { (methylamino) }\end{array}$ & Tyr 530, Asn 534 & Asn 360, Val 342 & -29.00 & -12.14 & 0.14 & -6.92 \\
\hline & Pseduosarsasapogenin-5,20-dien & Ser 15 & $\begin{array}{l}\text { Val 12, Asp 846, } \\
\text { Asn 414, Val } 12\end{array}$ & -56.41 & -29.45 & 6.51 & -12.54 \\
\hline & $\begin{array}{ll}\text { Oxiraneundecanoic } & \text { acid,3- } \\
\text { pentyl,methyl ester cis } & \\
\end{array}$ & no polar contact & $\begin{array}{l}\text { Lys 411, Ser 15, } \\
\text { Asn 414, Val } 12\end{array}$ & -46.14 & -22.77 & 5.77 & -11.38 \\
\hline & Pregabalin & $\begin{array}{l}\text { Asn 356, Tyr 530, } \\
\text { Asp 377 }\end{array}$ & Thr 344, Ser 343 & -30.35 & -13.26 & 0.32 & -6.85 \\
\hline & Arabidol & Asn 781 , Tyr 129 & $\begin{array}{l}\text { Lys } 780 \text {, Ser } 709 \text {, } \\
\text { Thr } 710 \text {, Ser } 784\end{array}$ & -41.54 & -20.55 & 5.40 & -9.95 \\
\hline \multirow[t]{13}{*}{$\begin{array}{l}\text { 3CL } \\
\text { Protease } \\
(6 \mathrm{M} 2 \mathrm{Q})\end{array}$} & 2,4,6-Pyrimidinetrione & $\begin{array}{l}\text { Met 6, Asp 295, Gln } \\
\text { 127, Val 296, Arg } \\
298\end{array}$ & $\begin{array}{l}\text { all side bonded by } \\
\text { Polar contacts }\end{array}$ & -16.68 & -7.33 & 0.09 & -4.42 \\
\hline & 21- Acetoxypregenelone & $\begin{array}{l}\text { Arg 188, Gln 184, } \\
\text { Thr 190, Met 165, } \\
\text { Glu 166, Leu 167, } \\
\text { Ser 46, Thr } 45\end{array}$ & $\begin{array}{l}\text { Thr 25, Thr 24, Thr } \\
26\end{array}$ & -28.57 & -14.64 & 8.41 & -9.22 \\
\hline & P- menth-8(10)-en-9-ol & Asn 142 & $\begin{array}{l}\text { Gly } 143 \text {, Cys } 145, \\
\text { His } 163 \text {, Asn } 143\end{array}$ & -24.19 & -11.51 & 2.27 & -.6 .75 \\
\hline & $\begin{array}{lr}\text { Nor-diazepam, } & 3\{\mathrm{n}- \\
\text { hydroxymethyl\}aminocarbonyloxy }\end{array}$ & $\begin{array}{l}\text { Met 165, Glu 166, } \\
\text { Asn } 142\end{array}$ & Ser 46 , Met 49 & -25.73 & -11.42 & 0.80 & -7.19 \\
\hline & Digitoxin & Gly 116 , Tyr 154 & $\begin{array}{l}\text { Asn 151, Asp 153, } \\
\text { Tyr 154, Phe 305, } \\
\text { Phe 294 }\end{array}$ & -54.15 & -27.23 & 6.90 & -13.27 \\
\hline & DI-N-Decylsulfone & $\begin{array}{l}\text { Phe 294, Gln 110, } \\
\text { Thr 111, Thr } 292\end{array}$ & Asp 295, Pro 293 & -28.23 & -14.86 & 5.07 & -7.39 \\
\hline & 14-dodecanoic acid & $\begin{array}{l}\text { Leu 253, Leu 250, } \\
\text { Ile 249, Pro } 252\end{array}$ & $\begin{array}{l}\text { Phe 294, Val 297, } \\
\text { Asp 248, Asp } 245\end{array}$ & -18.11 & -9.92 & 4.01 & -5.98 \\
\hline & Estra-1,3,5(10)-trien-17-beta-ol & $\begin{array}{l}\text { Phe 294, Pro 293, } \\
\text { Thr 111, Gln 110, } \\
\text { His } 246\end{array}$ & $\begin{array}{l}\text { all side bonded by } \\
\text { polar contacts }\end{array}$ & -19.00 & -10.41 & 3.39 & -5.43 \\
\hline & $\begin{array}{l}\text { Arachidonic amide,N-\{5-hydroxy- } \\
\text { N-Pentyl }\end{array}$ & Asn 142 , Gly 143 & $\begin{array}{l}\text { Ser 144, Glu 166, } \\
\text { Leu } 167\end{array}$ & -38.03 & -17.95 & 5.31 & -10.86 \\
\hline & $\begin{array}{l}\text { 1-methylsulfanyl-9-10-Dioxo-9,10- } \\
\text { dihydro-Anthracene-2-carboxylic } \\
\text { acid }\end{array}$ & Glu 166, Met 165 & $\begin{array}{l}\text { Ser 46, Thr 25, Glu } \\
47\end{array}$ & -39.16 & -16.63 & 4.12 & -12.29 \\
\hline & Cholesterol margarate & Gln 110, Gln 109 & Pro $108, G \ln 240$ & -40.95 & -23.94 & 9.46 & -9.91 \\
\hline & Docosanoic acid & no polar contacts & $\begin{array}{l}\text { Phe 294, Gln 110, } \\
\text { Thr 111, Asp } 153\end{array}$ & -28.31 & -14.82 & 1.65 & -6.51 \\
\hline & 26-hydroxycholesterol & $\begin{array}{l}\text { His 163, Met 165, } \\
\text { Glu } 166\end{array}$ & $\begin{array}{l}\text { Asn 142, Cys 145, } \\
\text { Ser 46, Thr } 45\end{array}$ & -40.85 & -17.40 & 4.98 & -12.61 \\
\hline
\end{tabular}




\begin{tabular}{|c|c|c|c|c|c|c|c|}
\hline & Andrographolide & $\begin{array}{l}\text { Thr 25, Ser } 46 \text {, Glu } \\
166 \text {, Met } 165\end{array}$ & Asn 142, His 41 & -24.51 & -13.53 & 7.31 & -7.17 \\
\hline & $\begin{array}{l}\text { 6H-purin-6-one,1,7-dihydro-2- } \\
\text { (methylamino) }\end{array}$ & $\begin{array}{l}\text { Glu 166, Met 165, } \\
\text { Leu 167, Cys } 145\end{array}$ & $\begin{array}{l}\text { His 163, Asn 142, } \\
\text { Gly } 143\end{array}$ & -21.58 & -8.97 & 2.01 & -6.60 \\
\hline & Pseduosarsasapogenin-5,20-dien & $\begin{array}{l}\text { Thr 243, Phe 294, } \\
\text { Thr 111, Gln } 110\end{array}$ & Thr 242, Asp 245 & -34.40 & -18.57 & 6.71 & -8.41 \\
\hline & $\begin{array}{ll}\text { Oxiraneundecanoic } & \text { acid,3- } \\
\text { pentyl,methyl ester cis } & \\
\end{array}$ & Gln 110, Gly 109 & $\begin{array}{l}\text { Phe 294, Pro 293, } \\
\text { His 246, Asr } 153\end{array}$ & -24.73 & -12.67 & 1.46 & -5.53 \\
\hline & Pregabalin & Arg 298, Met 6 & $\begin{array}{l}\text { Val 303, Thr 304, } \\
\text { Arg 298, Gln } 299 \\
\end{array}$ & -20.69 & -10.29 & 3.12 & -6.33 \\
\hline & Arabidol & $\begin{array}{l}\text { Glu 166, Met 165, } \\
\text { His } 164\end{array}$ & $\begin{array}{l}\text { Thr 26, Thr 25, Thr } \\
24, \text { Thr } 45\end{array}$ & -37.06 & -16.29 & 10.23 & -14.02 \\
\hline \multirow{19}{*}{$\begin{array}{l}\text { Spike } \\
\text { glycoprotein } \\
(6 \mathrm{LXT})\end{array}$} & 2,4,6-Pyrimidinetrione & $\begin{array}{l}\text { Val 952, Asn 955, } \\
\text { Asn 956, Asn } 953\end{array}$ & $\begin{array}{l}\text { all side bonded by } \\
\text { polar contact }\end{array}$ & -26.44 & -10.31 & 0.16 & -6.94 \\
\hline & 21- Acetoxypregenelone & $\begin{array}{l}\text { Ala } 942, \text { Ser } 940, \\
\text { Arg } 1185\end{array}$ & $\begin{array}{l}\text { Asn 1187, Ser 943, } \\
\text { Lys 1181, Ile } 183\end{array}$ & -28.10 & -19.75 & 5.74 & -2.22 \\
\hline & P- menth-8(10)-en-9-ol & Leu 922 & $\begin{array}{l}\text { Ile 923, Ala 924, } \\
\text { Asn 919, Gln 920 }\end{array}$ & -24.89 & -11.41 & 1.94 & -6.68 \\
\hline & $\begin{array}{lr}\text { Nor-diazepam, } & 3\{\mathrm{n}- \\
\text { hydroxymethyl\}aminocarbonyloxy }\end{array}$ & $\begin{array}{l}\text { Ile 1198, Asn 928, } \\
\text { Leu 1197 }\end{array}$ & Asp 1199, Asn 925 & -36.22 & -17.30 & 4.48 & -10.95 \\
\hline & Digitoxin & Ser 940, Arg 1185 & $\begin{array}{l}\text { Glu 1182, Ser 943, } \\
\text { Asp 936, Lys 1191, } \\
\text { Gln 935 }\end{array}$ & -63.54 & -42.37 & 17.15 & -8.93 \\
\hline & DI-N-Decylsulfone & Ser 940 & $\begin{array}{l}\text { Ser 943, Ser 939, } \\
\text { Lys 1181, Lys } 947 \\
\end{array}$ & -41.11 & -26.75 & 5.32 & -4.29 \\
\hline & 14-dodecanoic acid & Ser 939 & $\begin{array}{l}\text { Asn 1194, } \text { Asn } \\
\text { 1187, Glu 1188, } \\
\text { Glu 1195, Gln 935 } \\
\end{array}$ & -23.19 & -13.50 & 1.46 & -3.08 \\
\hline & Estra-1,3,5(10)-trien-17-beta-ol & Ala 1190, Lys 1191 & $\begin{array}{lll}\text { Arg } 1185, & \text { Asn } \\
1187, & \text { Gln 935 } & \\
\end{array}$ & -32.36 & -19.07 & 3.90 & -4.34 \\
\hline & $\begin{array}{l}\text { Arachidonic amide,N-\{5-hydroxy- } \\
\text { N-Pentyl }\end{array}$ & Lys 947 & $\begin{array}{l}\text { Asp } 1184, \quad \text { Glu } \\
\text { 1188, Asn 1187, } \\
\text { Asp 936, Lys } 1191 \text {, } \\
\text { Ser 939 }\end{array}$ & -42.54 & -27.63 & 3.87 & -2.74 \\
\hline & $\begin{array}{l}\text { 1-methylsulfanyl-9-10-Dioxo-9,10- } \\
\text { dihydro-Anthracene-2-carboxylic } \\
\text { acid }\end{array}$ & $\begin{array}{l}\text { Asp 184, Ser 940, } \\
\text { Arg 1185, Lys } 947\end{array}$ & Ser 943, Ser 949 & -31.67 & -21.43 & 1.25 & -0.52 \\
\hline & Cholesterol margarate & no polar contact & $\begin{array}{llr}\text { Asn } 1184, & \text { Asn } \\
\text { 1187, } & \text { Asp 936, Gln } \\
935 & & \\
\end{array}$ & -54.12 & -32.79 & 9.27 & -8.23 \\
\hline & Docosanoic acid & Asn 1178, Lys 1181 & $\begin{array}{l}\text { Ser 943, Ser 939, } \\
\text { Lys 947, Gln } 935\end{array}$ & -37.20 & -26.13 & 3.97 & -2.01 \\
\hline & 26-hydroxycholesterol & $\begin{array}{l}\text { Asn 925, Gln 926, } \\
\text { Lys } 1191\end{array}$ & $\begin{array}{l}\text { Gln 1195, Asp 936, } \\
\text { Gly 932, Asn } 928 \\
\end{array}$ & -41.67 & -20.53 & 2.58 & -8.23 \\
\hline & Andrographolide & $\begin{array}{l}\text { Gln 920, Lys 921, } \\
\text { Tyr } 917\end{array}$ & Glu 1202, Val 915 & -29.04 & -21.14 & 20.25 & -9.23 \\
\hline & $\begin{array}{l}\text { 6H-purin-6-one,1,7-dihydro-2- } \\
\text { (methylamino) }\end{array}$ & Tyr 917 & $\begin{array}{lll}\text { Leu } & 1200, & \text { Asp } \\
1199, & \text { Tyr 917 } & \\
\end{array}$ & -19.45 & -8.27 & 0.66 & -5.86 \\
\hline & Pseduosarsasapogenin-5,20-dien & Ser 939 & $\begin{array}{l}\text { Ser 940, Glu 1182, } \\
\text { Lys } 1181\end{array}$ & -41.80 & -28.41 & 2.51 & -2.20 \\
\hline & $\begin{array}{ll}\begin{array}{l}\text { Oxiraneundecanoic } \\
\text { pentyl,methyl ester cis }\end{array} & \text { acid,3- } \\
\end{array}$ & Lys 1181 & $\begin{array}{l}\text { Arg 1181, Asp 936, } \\
\text { Ser 943, Ser } 939 \\
\end{array}$ & -34.65 & -25.21 & 6.80 & -2.26 \\
\hline & Pregabalin & no polar contacts & $\begin{array}{l}\text { Leu 1200, Ile 923, } \\
\text { Ala } 924\end{array}$ & -27.07 & -13.01 & 2.00 & -6.29 \\
\hline & Arabidiol & $\begin{array}{l}\text { Arg 1185, Leu } \\
\text { 1186, Asp 1184 }\end{array}$ & $\begin{array}{lcc}\text { Lys } 1181, & \text { Asn } \\
1187, & \text { Ser } 943 & \end{array}$ & -29.82 & -22.67 & 4.74 & 0.13 \\
\hline
\end{tabular}

Table 5 Drug-likeness analysis of bioactive compounds showing good binding energy against SARS-CoV-2 proteins 


\begin{tabular}{|c|c|c|c|c|c|c|c|c|c|c|}
\hline \multirow[t]{2}{*}{ ass compounds } & \multicolumn{5}{|c|}{ Physicochemical properties (Lipinski rule of Five) } & \multicolumn{3}{|l|}{ Solubility } & \multicolumn{2}{|c|}{ Pharmacokinetics } \\
\hline & MW & $\begin{array}{l}\text { HB } \\
\text { donors }\end{array}$ & $\begin{array}{l}\mathrm{HB} \\
\text { acceptors }\end{array}$ & $\begin{array}{l}\text { No of } \\
\text { rotatable } \\
\text { bond }\end{array}$ & $\begin{array}{l}\text { consensus } \\
\log \mathrm{P}\end{array}$ & $\begin{array}{l}\text { Log S } \\
(\mathrm{ESOL})\end{array}$ & Log S (Ali) & $\begin{array}{l}\text { Log S } \\
\text { (SILICOS- } \\
\text { IT) }\end{array}$ & $\begin{array}{l}\text { GI } \\
\text { absorption }\end{array}$ & $\begin{array}{l}\text { CYP } \\
\text { enzymes } \\
\text { inhibitors } \\
\end{array}$ \\
\hline & 764 & 5 & 13 & 7 & 2.61 & $\begin{array}{l}\text { moderately } \\
\text { soluble }\end{array}$ & $\begin{array}{l}\text { moderately } \\
\text { soluble }\end{array}$ & $\begin{array}{l}\text { moderately } \\
\text { soluble }\end{array}$ & low & no \\
\hline 'cholesterol & 402 & 2 & 2 & 6 & 5.86 & $\begin{array}{l}\text { poorly } \\
\text { soluble }\end{array}$ & $\begin{array}{l}\text { poorly } \\
\text { soluble }\end{array}$ & $\begin{array}{l}\text { moderately } \\
\text { soluble }\end{array}$ & high & no \\
\hline c amide,N-\{5-hydroxy- & 389 & 2 & 2 & 20 & 6.27 & $\begin{array}{l}\text { moderately } \\
\text { soluble }\end{array}$ & $\begin{array}{l}\text { poorly } \\
\text { soluble }\end{array}$ & $\begin{array}{l}\text { poorly } \\
\text { soluble }\end{array}$ & high & no \\
\hline margarate & 639 & 0 & 2 & 22 & 12.43 & insoluble & insoluble & insoluble & low & no \\
\hline pregenolone & 374 & 1 & 4 & 4 & 3.77 & $\begin{array}{l}\text { moderately } \\
\text { soluble }\end{array}$ & soluble & soluble & high & $\begin{array}{l}\text { only } \\
\text { CYP2C9 } \\
\text { inhibitor } \\
\end{array}$ \\
\hline sulfone & 346 & 0 & 2 & 18 & 6.68 & $\begin{array}{l}\text { poorly } \\
\text { soluble }\end{array}$ & $\begin{array}{l}\text { poorly } \\
\text { soluble }\end{array}$ & $\begin{array}{l}\text { poorly } \\
\text { soluble }\end{array}$ & low & $\begin{array}{l}\text { CYP2C9, } \\
\text { CYP1A2 } \\
\text { inhibitor } \\
\end{array}$ \\
\hline asapogenin-5,20-dien & 414 & 2 & 3 & 4 & 4.86 & $\begin{array}{l}\text { moderately } \\
\text { soluble }\end{array}$ & $\begin{array}{l}\text { moderately } \\
\text { soluble }\end{array}$ & $\begin{array}{l}\text { moderately } \\
\text { soluble }\end{array}$ & high & no \\
\hline $\begin{array}{l}\text { am,3-\{N- } \\
\text { thyl\}aminocarbonyloxy } \\
\end{array}$ & 373 & 2 & 5 & 5 & 2.16 & soluble & soluble & soluble & high & no \\
\hline \multirow[t]{2}{*}{ holide } & 350 & 3 & 5 & 3 & 2.33 & soluble & soluble & soluble & high & no \\
\hline & 159 & 2 & 3 & 5 & 0.56 & $\begin{array}{l}\text { highly } \\
\text { soluble }\end{array}$ & $\begin{array}{l}\text { highly } \\
\text { soluble }\end{array}$ & soluble & high & no \\
\hline 10)-en-9-ol & 154 & 1 & 1 & 2 & 2.55 & soluble & soluble & soluble & high & no \\
\hline \multirow[t]{2}{*}{ acid } & 340 & 1 & 2 & 20 & 7.40 & $\begin{array}{l}\text { poorly } \\
\text { soluble }\end{array}$ & insoluble & $\begin{array}{l}\text { poorly } \\
\text { soluble }\end{array}$ & low & $\begin{array}{l}\text { CYP1A2 } \\
\text { inhibitor }\end{array}$ \\
\hline & 444 & 2 & 2 & 7 & 6.97 & $\begin{array}{l}\text { poorly } \\
\text { soluble }\end{array}$ & $\begin{array}{l}\text { poorly } \\
\text { soluble }\end{array}$ & $\begin{array}{l}\text { poorly } \\
\text { soluble }\end{array}$ & low & no \\
\hline
\end{tabular}

\section{Figures}



Spike glyoagroxtin S2 suburil prost fusian PDe 10: 6LXT

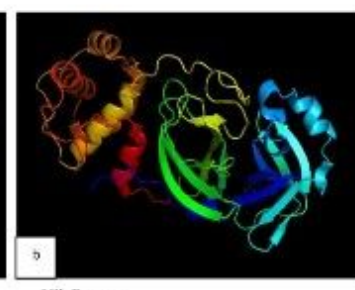

SCL. Pmeane
POB ID: 6 SI2



RNA-dipenien HNA-polymemas

PDB ID: $6 \mathrm{M} 71$

\section{Figure 1}

The 3D ribbon structures representation of SARS-CoV-2 target proteins (a) spike glycoprotein S2 subunit post-fusion core (b) 3CL protease and (c) RNA-dependent RNA polymerase visualized using PyMol 


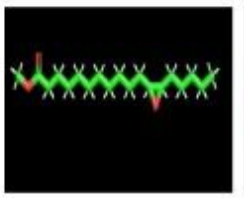

Oxirsneundecanoic acid, centy, (mettryl

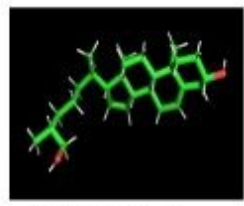

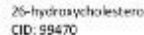

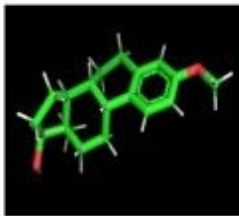

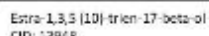

CID: $: 3965$



2.4,6- Pyrimidentiane

(1): 5211
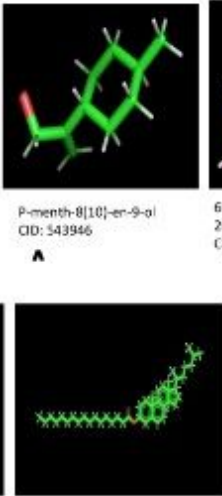

Chulesiter
10572941

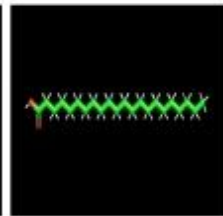

Docosanaik acid
OCF: 8225



Psed.oosars:
C10:261799

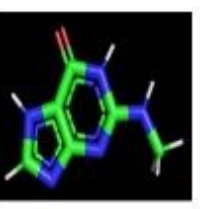

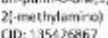

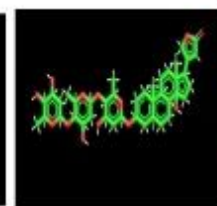

Digtaxin
CID. $4<1307$

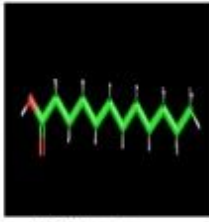

14-Dodecinoic



1-meathysulfant-9, 10-dian -9,10.

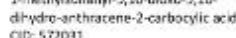

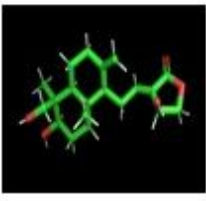

Androersoholide
C10. 531551 ?

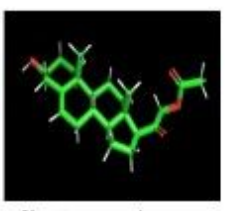

21-scesaryprepenselane

(10.2010

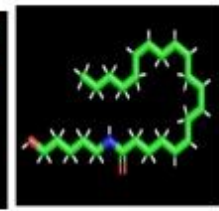

Arsachidoric armide, N-15-

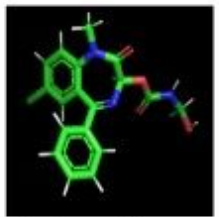

Ner-diasepam, 3-1ht.
hydroxymethyleminocarbomy lowy
CID: 541751

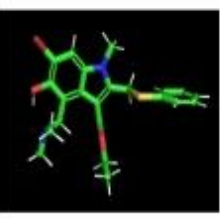

Arabidial
Gio- 131411

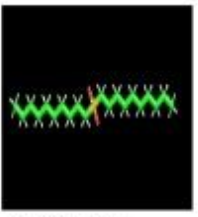

ar-N-decylbulfare

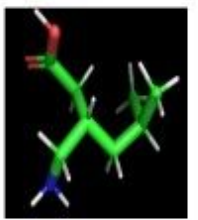

Pregstolin
C.ID. 5485971

Figure 2

GC-MS compounds and positive control Arabidol ligands downloaded from PubChem data bank with compound ID and visualized using PyMol for molecular docking



Figure 3 
GC-MS spectrograms showing peaks of compounds of Pleione maculata extracts (a) acetone (b) ethanol (c) methanol extracts of (i) leave (ii) stem and (iii) root
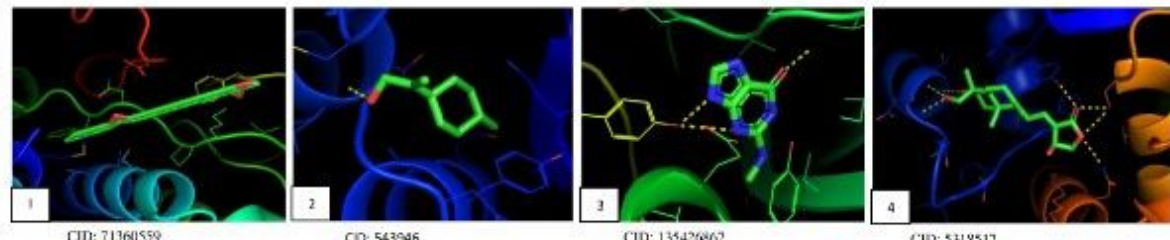

तก: 71361559

mansas

CID: 13542606 ?
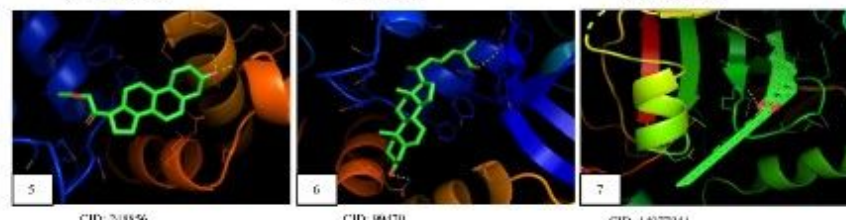

CiD: 5318517

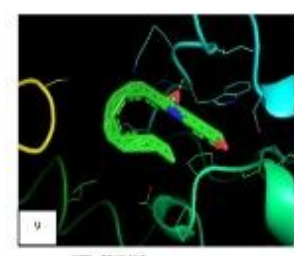

(ID: 1 (क) $\pi$ अ
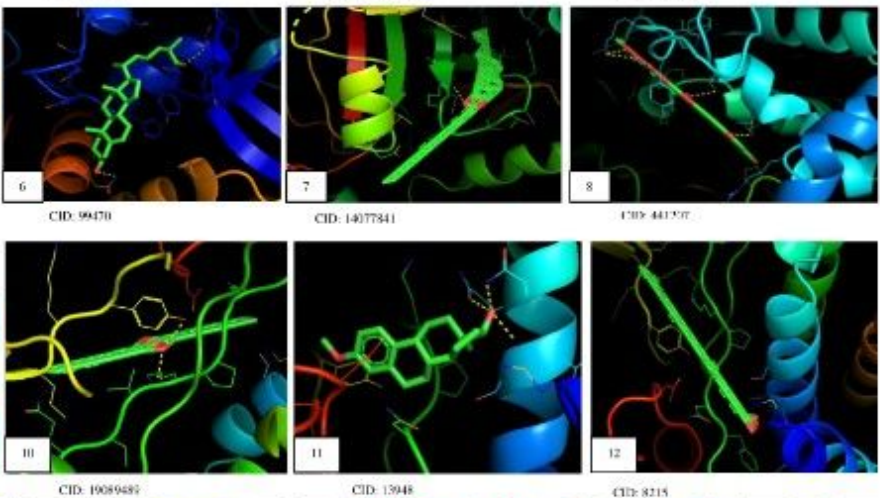

CII: 528:405

CID 1905ose?
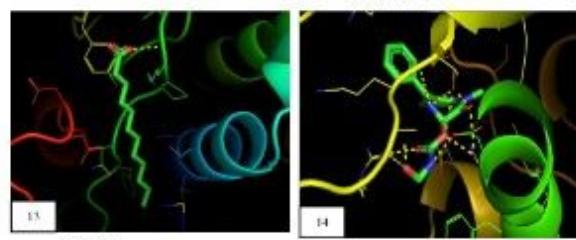

$201 \times 9472+1$

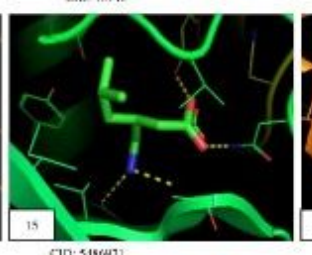

(17.

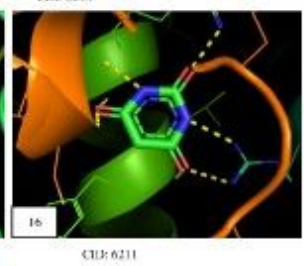

410:3sv:
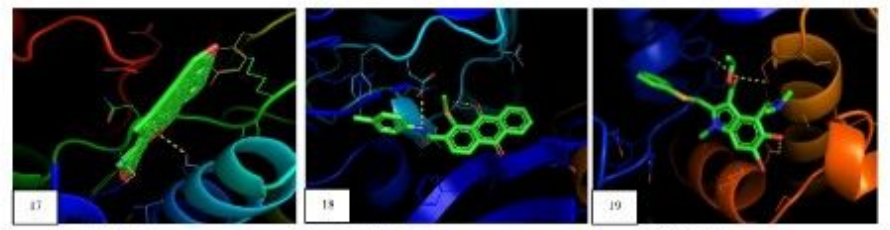

(19:0211

c1n: $2615 \%$

모. $552 m$

(11) 1344!

\section{Figure 4}

Molecular docking of target SARS-CoV-2 RNA-dependent RNA-polymerase (PDB ID- 6M71) with the S-CoV-2 RNA-dependent RNA polymerase (PDB ID-6M71) with the GC-MS bioactive compounds of Pleione maculata (1) Oxiraneundecanoic acid,3-pentyl,methyl ester, cis (2) p-menth-8(10)-en-9-ol (3) 6H-purin-6-one,1,7-dihydro-(2-methylamino) (4) Andrographolide (5) 21-acetoxypregenelone (6) 26hydroxycholesterol (7) Cholesterol margarate (8) Digitoxin (9) Arachidonic amide, N-\{5-hydroxy-N-pentyl\} (10) DI-N-decylsulfone (11) Estra1,3,5(10)-trien-beta-ol (12) Docosanoic acid (13) 14-dodecanoic acid (14) Nor-diazepam,3-\{N-hydroxymethyl\}aminocarbonyloxy (15) Pregabalin (16) 2,4,6-pyrimidinetrione (17) pseduosarsasapogenin acid, 3-pentyl, methyl ester cis, (18) 1-methylsulfanyl-9,10-dioxo-9, 10dihydro-anthracene-2-carboxylic acid and positive control (19) arabidiol 

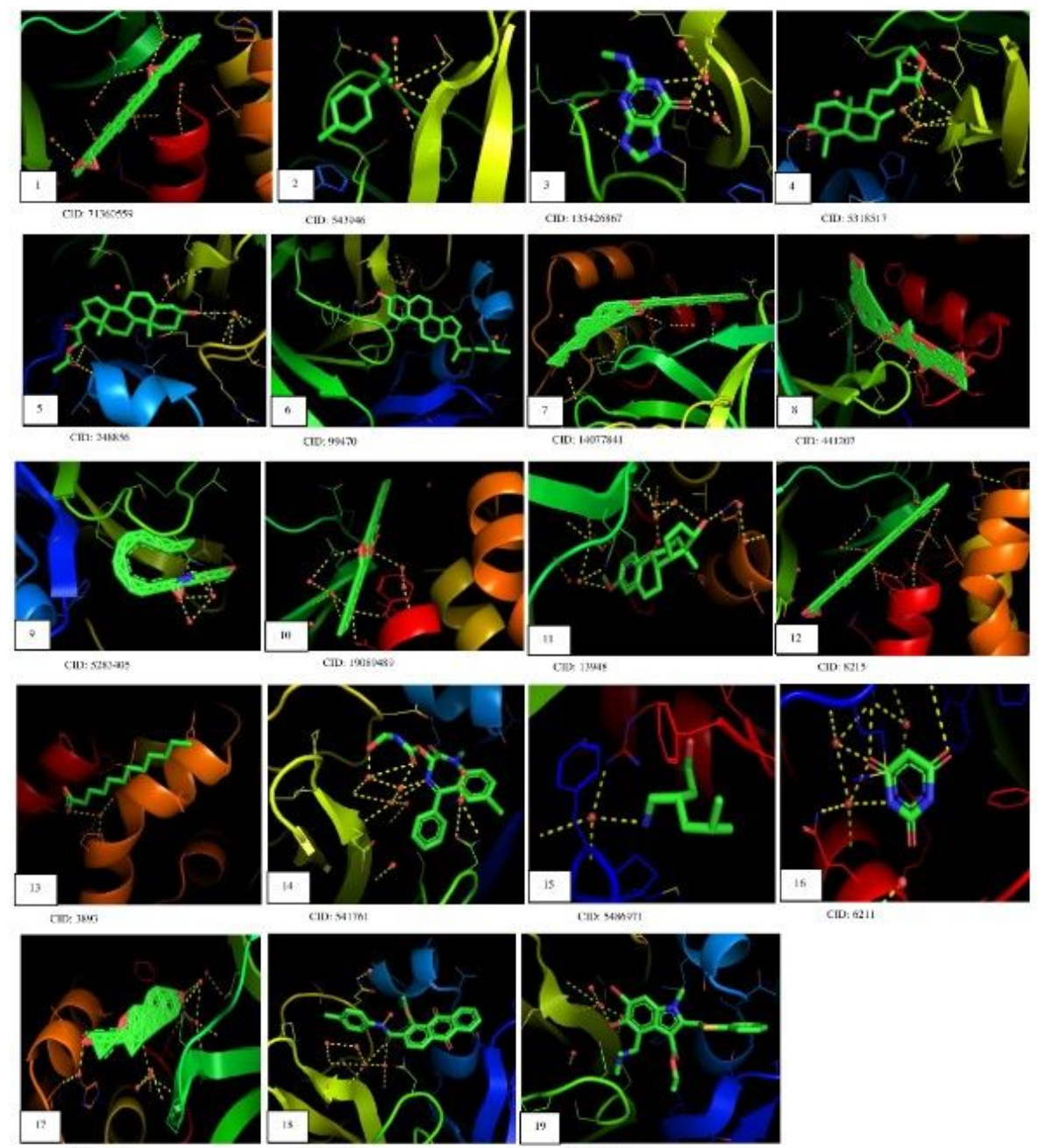

$\operatorname{cin} x \sin 3 \pi 1$
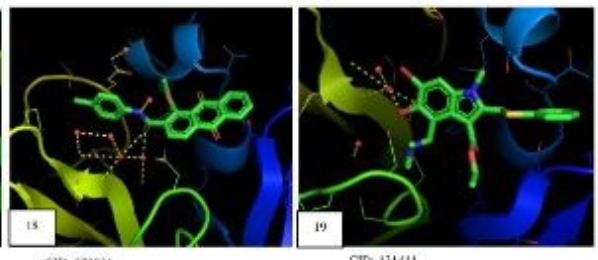

CII 2 ลก:

a1: :572051

CID. 13411

\section{Figure 5}

Molecular docking of target SARS-CoV-2 3CL Protease (PDB ID-6M2Q) with the GC-MS bioactive compounds of Pleione maculata (1) Oxiraneundecanoic acid,3-pentyl,methyl ester, cis (2) p-menth-8(10)-en-9-ol (3) 6H-purin-6-one,1,7-dihydro-(2-methylamino) (4) Andrographolide (5) 21-acetoxypregenelone (6) 26-hydroxycholesterol (7) Cholesterol margarate (8) Digitoxin (9) Arachidonic amide, N-\{5hydroxy-N-pentyl\} (10) DI-N-decylsulfone (11) Estra-1,3,5(10)-trien-beta-ol (12) Docosanoic acid (13) 14-dodecanoic acid (14) Nordiazepam,3-\{N-hydroxymethyl\}aminocarbonyloxy (15) Pregabalin (16) 2,4,6-pyrimidinetrione (17) pseduosarsasapogenin acid, 3-pentyl, methyl ester cis, (18) 1-methylsulfanyl-9,10-dioxo-9, 10-dihydro-anthracene-2-carboxylic acid and positive control (19) arabidiol 

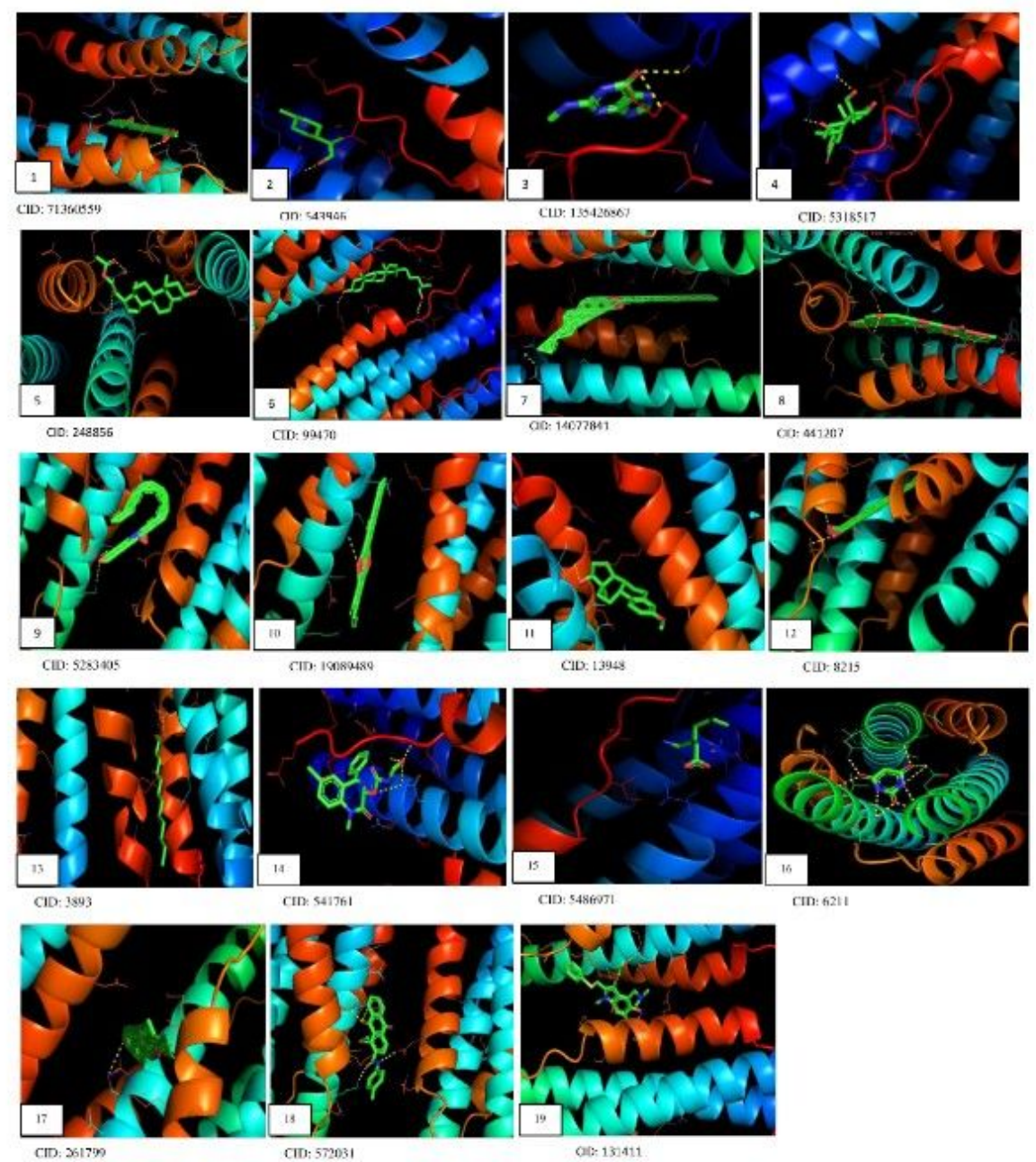

\section{Figure 6}

Molecular docking of target SARS-CoV-2 spike glycoprotein S2 subunit (PDB ID- 6LXT) with the GC-MS bioactive compounds of Pleione maculata (1) Oxiraneundecanoic acid,3-pentyl,methyl ester, cis (2) p-menth-8(10)-en-9-ol (3) 6H-purin-6-one,1,7-dihydro-(2-methylamino) (4) Andrographolide (5) 21-acetoxypregenelone (6) 26-hydroxycholesterol (7) Cholesterol margarate (8) Digitoxin (9) Arachidonic amide, N-\{5hydroxy-N-pentyl\} (10) DI-N-decylsulfone (11) Estra-1,3,5(10)-trien-beta-ol (12) Docosanoic acid (13) 14-dodecanoic acid (14) Nordiazepam,3-\{N-hydroxymethyl\}aminocarbonyloxy (15) Pregabalin (16) 2,4,6-pyrimidinetrione (17) pseduosarsasapogenin acid, 3-pentyl, methyl ester cis, (18) 1-methylsulfanyl-9,10-dioxo-9, 10-dihydro-anthracene-2-carboxylic acid and positive control (19) arabidiol 

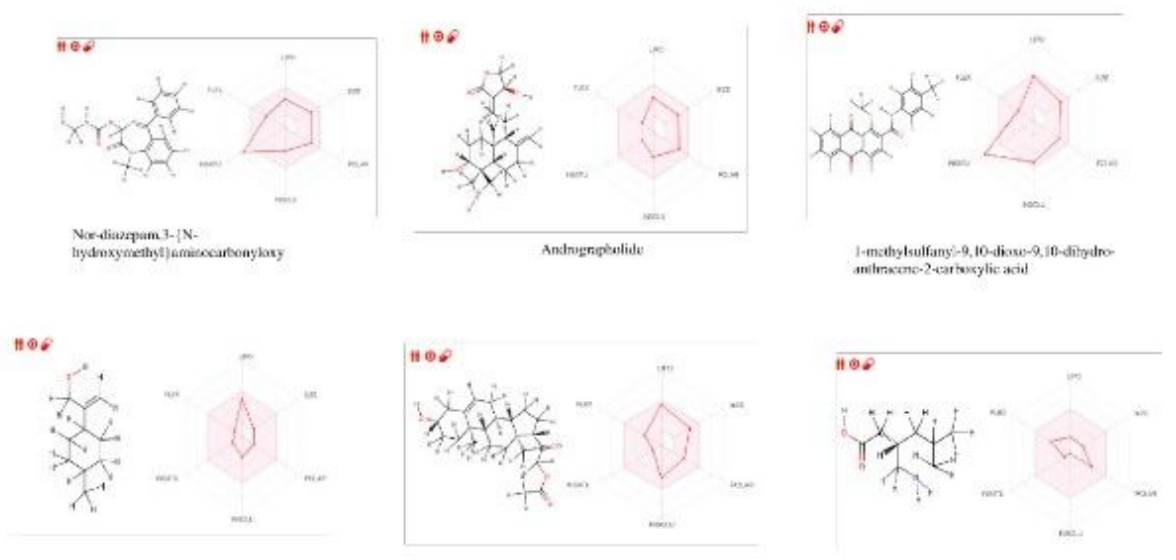

Pmenth-8(10)-en 9 ol

$21-$-xadorymegenive



Psedicsarsasapog:ain-5.211-diea
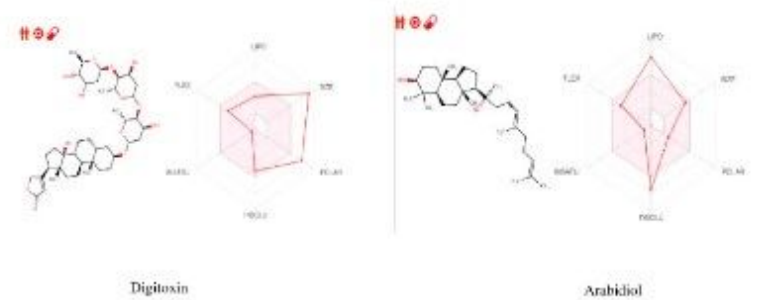

\section{Figure 7}

The bioavailibility radar of different bioactive drug-likeness molecules were the pink areas represents each properties (Lipophilicity, molecular weight, solubility, flexiibility)

\section{Supplementary Files}

This is a list of supplementary files associated with this preprint. Click to download.

- FigureS1.jpg

- FigureS2.jpg 